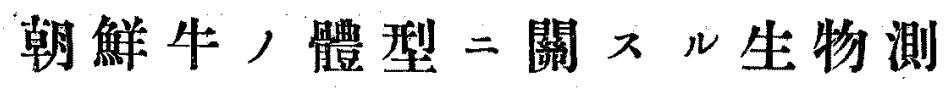 定學的研究 (第一報)
}

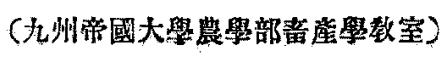

\section{金 谷 復 五 郎}

\section{I 緒 諭}

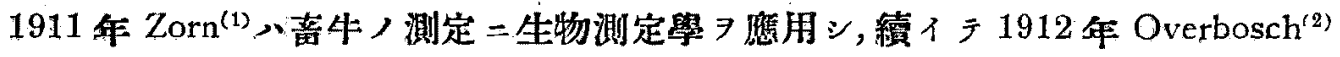

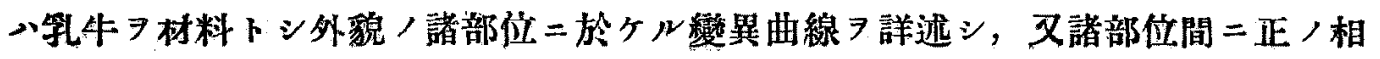

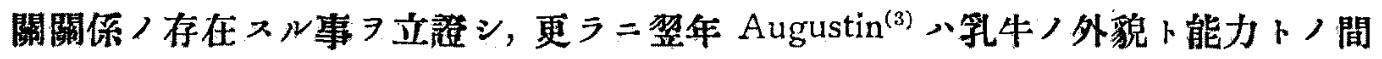

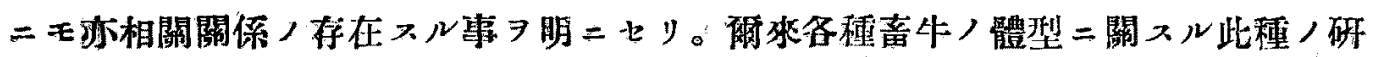

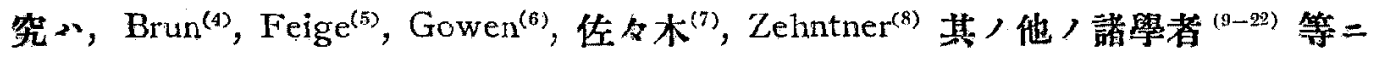
ヨリラ論究セラレタリ。然レドモ是等ノ研究ハ主トシラ学牛 $ヨ$ 材料トシ肉牛又心 争用牛 ヨ材料!七ルモノ、少ク，殊二專用タル役牛二於ヶル研究川余，寡聞ナル 未㫖ョ聞カズ。

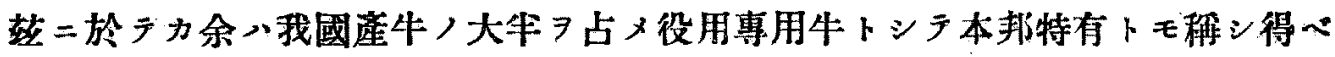

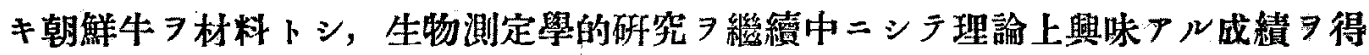
タルバナラズ，實地二音牛，改良 ヨ行フ場合二當リラ必要タルベキ標準體型

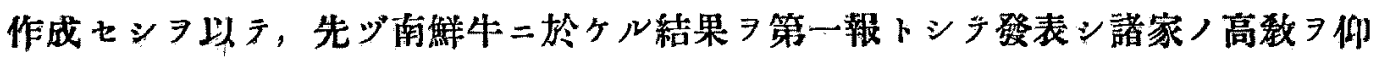
ギ今後 研究二資セントス。

\section{II 研究材料及ヒ匕方法}

朝鮮这牛，總頭數》約 160 萬頭ニシラ殆ンド全部 $(99.9 \%)$ 役用タル朝鮮牛ナ リ，且朝鮮牛入朝鮮二於々几役畜ノ $96 \% \ni$ 占タ，一般二性質溫順二シテ體質强 健, 殊二持久力二富 ミ飼養管理容易ニシテ, 專ラ農耕運搬等二使役セラレ役音卜 シテ最モ重要ナル家苗ナリ。加フルニ農家ノ貴重ナル財產ナルト同時二農村二於 ケル唯一ノ金融機關タリ。又一方二於テハ米及ビ大豆二次イデ重要ナル貿易品二 シラ，朝鮮本土ヨリ各地二年々数萬頭 二重要ナル地位 $ヨ$ 占ムルカヨ知ルベシ ${ }^{(23)}$ 。

夯二朝鮮牛，系統二關シラ望月 ${ }^{(24)}$ ガ考古學，古生物學，骨學及ビ胎生學的見地

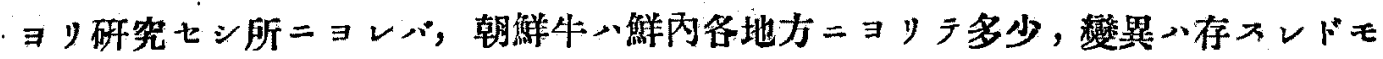




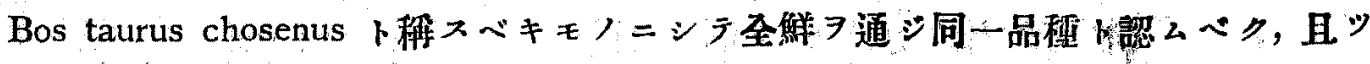
類原牛 Bos taurus primigenius Rütimeyer 二酷似ストセり。

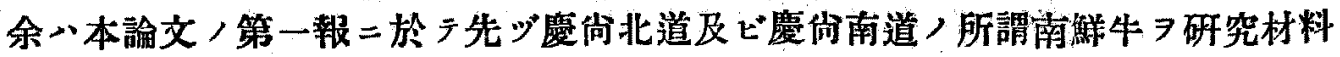

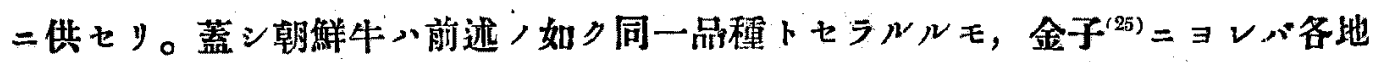

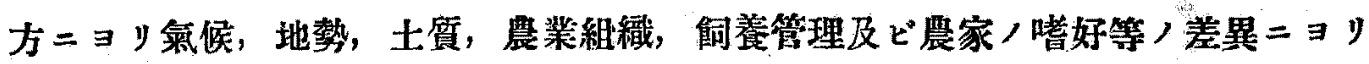
多年地方的二特色アル蕃殖

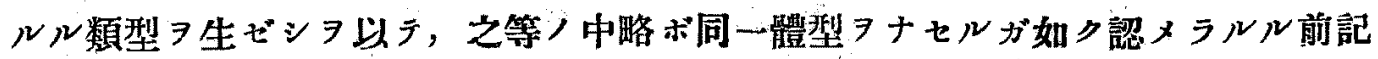
二道，畜牛 $ー$ 一括シテ测定シタルタ以テナリ。余ハ昭和二年七月以降二於テ前記

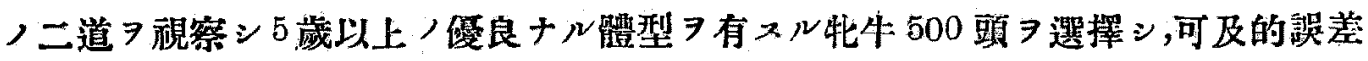
ヨ最小ナラシムル篇常二余ガ所持スル Lydtin 式ノ測杖 ${ }^{(26)}$ ， Hauptner 式ノKalli-

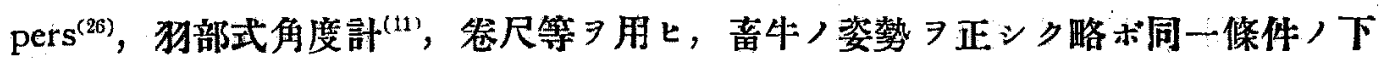

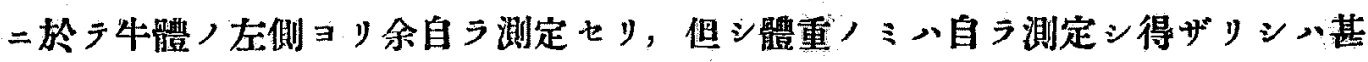
ダ遺喊トスル所ナリ。

測定部位一輴甲高，十字部高，坐骨端高，肘高，飛節高，胸深，前胸幅，胸幅， 腰角幅, 膛幅, 坐骨幅, 體長, 肩長, 尼長, 頭長, 胸圍, 前管圍, 後管圍, 飛節角

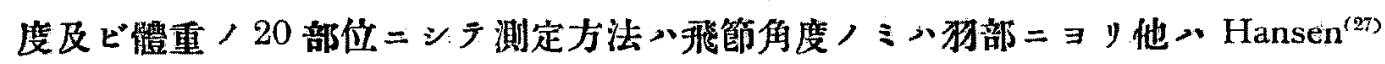
八例二做ヒタリ。

普通用ヒチルル方法 ${ }^{(28-30)}=$ ヨり先ヅ是等／各部位ニツキ生物測定學的恒數

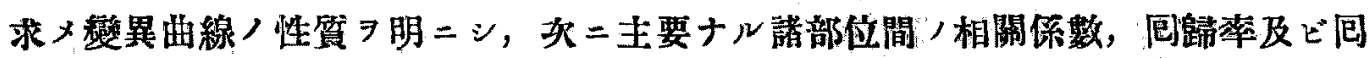
歸方程式 $\exists$ 求 $メ$ ，更二人類學二於ヶ

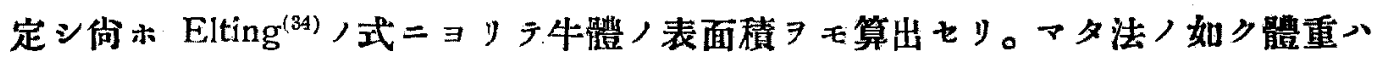

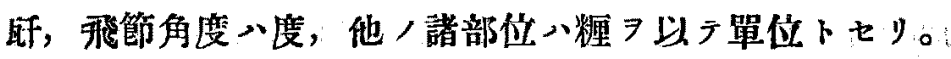

\section{III 生物測定學的恒數及ビ變異曲線}

\section{(1) 生物測定學的恒數}

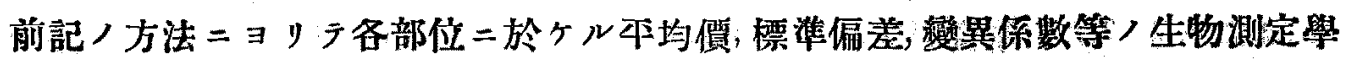
的恒數 7 算出シ一括シテ示をバ第一表ノ如ク，標潐偏考心體重二於テ著シク大二 シテ之ヨ除ケバ 0.62 ョリ 6.73 間二アリラ前管圍最モ小ニシテ次二後管圍, 坐

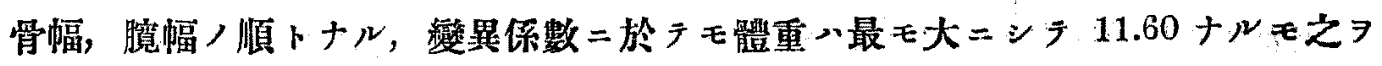

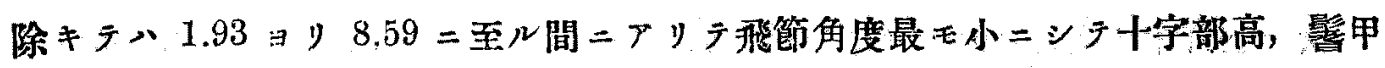

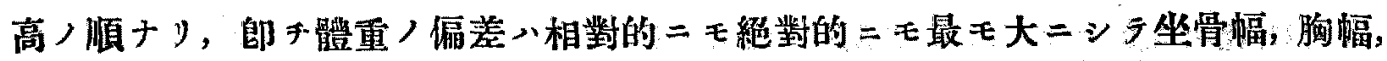




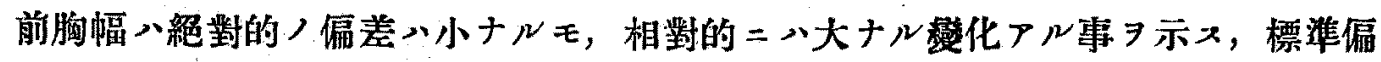

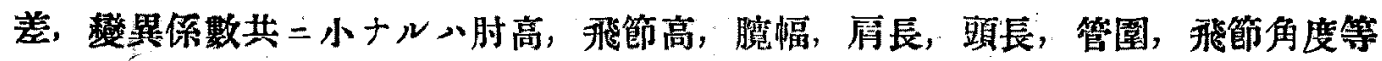
ナリ。而シテ余ノ南鮮牛二於ケル變是係數 1925 年= Momsen ${ }^{(18)}$, HolsteinFriesian 牝牛 499 頡及ビ Rümker ${ }^{(20)} ，$ Shorthorn 牝牛 103 顥ニッキラ得タル結 果ト對比スルン（第二表照）比較的ヨク近似シ，何レノ場合二於テモ前胸幅， 胸幅，坐骨幅，變異係数、他，部位二比シテ大ナレド、篦甲高及ビ十字部高二

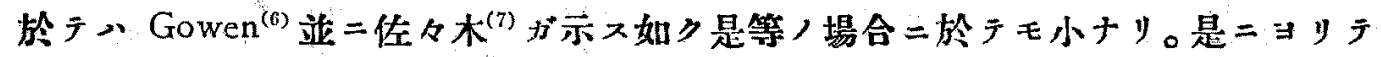

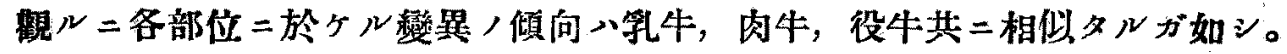

前迅ノ如ク 500 頙ノ比牛二於ヶル體重，測定材料 7 得タル

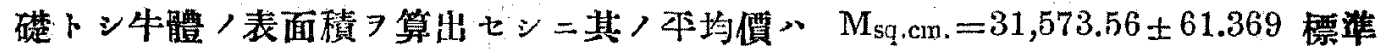
偏差、 $\sigma=2,032.09 \pm 43.284$ 變異係數、 $\mathrm{V}=6.44 \pm 0.128$ ナリ。

第一表 生物测定學的恒數 (其一)

\begin{tabular}{|c|c|c|c|c|c|}
\hline 部 位 & & M & $\sigma$ & $\dot{v}$ & $q_{1}$ \\
\hline 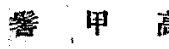 & 高 & $117.66 \pm 0.108$ & $3.57 \pm 0.076$ & $3.03 \pm 0.065$ & $114.97 \pm 0.147$ \\
\hline 十学部 吉 & 高 & $118.72 \pm 0.093$ & $3.12 \pm 0.066$ & $2.62 \pm 0.055$ & $116.45 \pm 0.127$ \\
\hline 坐 骨 端 & 高 & $103.41 \pm 0.096$ & $3.18 \pm 0.067$ & $3.08 \pm 0.065$ & $101.08 \pm 0.130$ \\
\hline 肘 & 高 & $64.78 \pm 0.060$ & $2.01 \pm 0.042$ & $3.10 \pm 0.066$ & $63.40 \pm 0.082$ \\
\hline 節 & 高 & $44.24 \pm 0.048$ & $1.59 \pm 0.034$ & $3.59 \pm 0.076$ & $43.11 \pm 0.067$ \\
\hline 跑 & 深 & $62.54 \pm 0.072$ & $2.39 \pm 0.051$ & $3.81 \pm 0.081$ & $60.88 \pm 0.097$ \\
\hline 胸 & 幅 & $34.18 \pm 0.065$ & $2.17 \pm 0.046$ & $6.37 \pm 0.136$ & $32.61 \pm 0.089$ \\
\hline 胸 & 幅 & $33.76 \pm 0.078$ & $2.57 \pm 0.055$ & $7.61 \pm 0.161$ & $31.87 \pm 0.104$ \\
\hline 角 & 潭 & $41.24 \pm 0.067$ & $2.23 \pm 0.047$ & $5.40 \pm 0.115$ & $39.55 \pm 0.091$ \\
\hline 靦 & 幅 & $37.80 \pm 0.045$ & $1.49 \pm 0.032$ & $3.94 \pm 0.084$ & $36.58 \pm 0.059$ \\
\hline 骨 & 幅 & $12.74 \pm 0.032$ & $1.09 \pm 0.023$ & $8.59 \pm 0.181$ & $12.00 \pm 0.044$ \\
\hline 鰉 & 長 & $135.68 \pm 0.140$ & $4.65 \pm 0.099$ & $3.43 \pm 0.073$ & $132.15 \pm 0.197$ \\
\hline 㕎 & 長 & $46.73 \pm 0.059$ & $1.94 \pm 0.041$ & $4.15 \pm 0.088$ & $45.17 \pm 0.076$ \\
\hline 层 & 長 & $43.06 \pm 0.062$ & $2.04 \pm 0.043$ & $4.74 \pm 0.101$ & $41.55 \pm 0.082$ \\
\hline 頭 & 長. & $44.80 \pm 0.054$ & $1.81 \pm 0.038$ & $4.02 \pm 0.085$ & $43.72 \pm 0.073$ \\
\hline 胸 & 闇 & $154.51 \pm 0.203$ & $6.73 \pm 0.143$ & $4.36 \pm 0.093$ & $148.95 \pm 0.271$ \\
\hline 前 管 & 啕 & $15.18 \pm 0.019$ & $0.62 \pm 0.013$ & $4.08 \pm 0.087$ & $14.69 \pm 0.025$ \\
\hline 挠＼cjkstart管 & 图 & $16.79 \pm 0.020$ & $0.68 \pm 0.014$ & $4.02 \pm 0.085$ & $16.24 \pm 0.027$ \\
\hline 感節角： & 度 & $148.49 \pm 0.086$ & $2.86 \pm 0060$ & $1.93 \pm 0.041$ & $146.20 \pm 0.117$ \\
\hline 體 & 重 & $240.12 \pm 0.824$ & $27.87 \pm 0.594$ & $11.60 \pm 0.259$ & $218.64 \pm 1.149$ \\
\hline
\end{tabular}


第一表 生物測定學的恒數（其二）

\begin{tabular}{|c|c|c|c|c|}
\hline 部 估 & 踏 & $q 8$ & Mi & $\begin{array}{l}\text { Mo } \\
\end{array}$ \\
\hline 祣甲 & 高 & $119.98 \pm 0.147$ & $117.33 \pm 0.135$ & $116.50 \pm 0.042$ \\
\hline 十学部 & 高 & $120.83 \pm 0.127$ & $118.47 \pm 0.117$ & $117.60 \pm 0.037$ \\
\hline 坐 骨 端 & 高 & $105.57 \pm 0.130$ & $103.19 \pm 0.120$ & $103.50 \pm 0.037$ \\
\hline 时 & 高 & $65.89 \pm 0.082$ & $64.55 \pm 0.075$ & $65.00 \pm 0.024$ \\
\hline 䞔 & 高 & $45.15 \pm 0.067$ & $44.09 \pm 0.061$ & $44.00 \pm 0.019$ \\
\hline 胸 & 深 & $64.12 \pm 0.097$ & $62.28 \pm 0.169$ & $61.00 \pm 0.028$ \\
\hline 胸 & 幅 & $35.32 \pm 0.089$ & $33.99 \pm 0.082$ & $34.00 \pm 0.025$ \\
\hline 眴 & 酔 & $35.32 \pm 0,104$ & $33.58 \pm 0,096$ & $32.00 \pm 0.030$ \\
\hline 腰 & 輻 & $42.66 \pm 0.091$ & $41,12 \pm 0.083$ & $42.00 \pm 0.026$ \\
\hline 䚋 & 幅 & $38.72 \pm 0.059$ & $37.65 \pm 0.054$ & $38.00 \pm 0.017$ \\
\hline 货 & 幅 & $13.56 \pm 0.044$ & $12.78 \pm 0.041$ & $13.00 \pm 0.013$ \\
\hline 瀜 & 唇 & $138.91 \pm 0.197$ & $135.07 \pm 0.181$ & $132.50 \pm 0.054$ \\
\hline 厦 & 長 & $47.94 \pm 0.076$ & $46.62 \pm 0.070$ & $47.00 \pm 0.023$ \\
\hline 鹿 & 唇 & $44.34 \pm 0.082$ & $42.79 \pm 0.075$ & $42.00 \pm 0.024$ \\
\hline 頙 & 長 & $46.20 \pm 0.073$ & $45.02 \pm 0.068$ & $46.00 \pm 0.021$ \\
\hline 琎 & 周 & $158.65 \pm 0.271$ & $153.30 \pm 0.249$ & $156.00 \pm 0.079$ \\
\hline 前 管 & 圍 & $15.56 \pm 0.025$ & $15.13 \pm 0.023$ & $15.10 \pm 0.007$ \\
\hline 後，管 & 黨 & $17.14 \pm 0.027$ & $16.72 \div 0.025$ & $16.80 \pm 0.008$ \\
\hline 節 角 & 度 & $149.78 \pm 0.117$ & $148.02 \pm 0.107$ & $149.00 \pm 0.033$ \\
\hline 韫 & 重 & $259.21 \pm 1.149$ & $238.16 \pm 1.057$ & $222.00 \pm 0.326$ \\
\hline
\end{tabular}

第二 表 變異係數，比輍

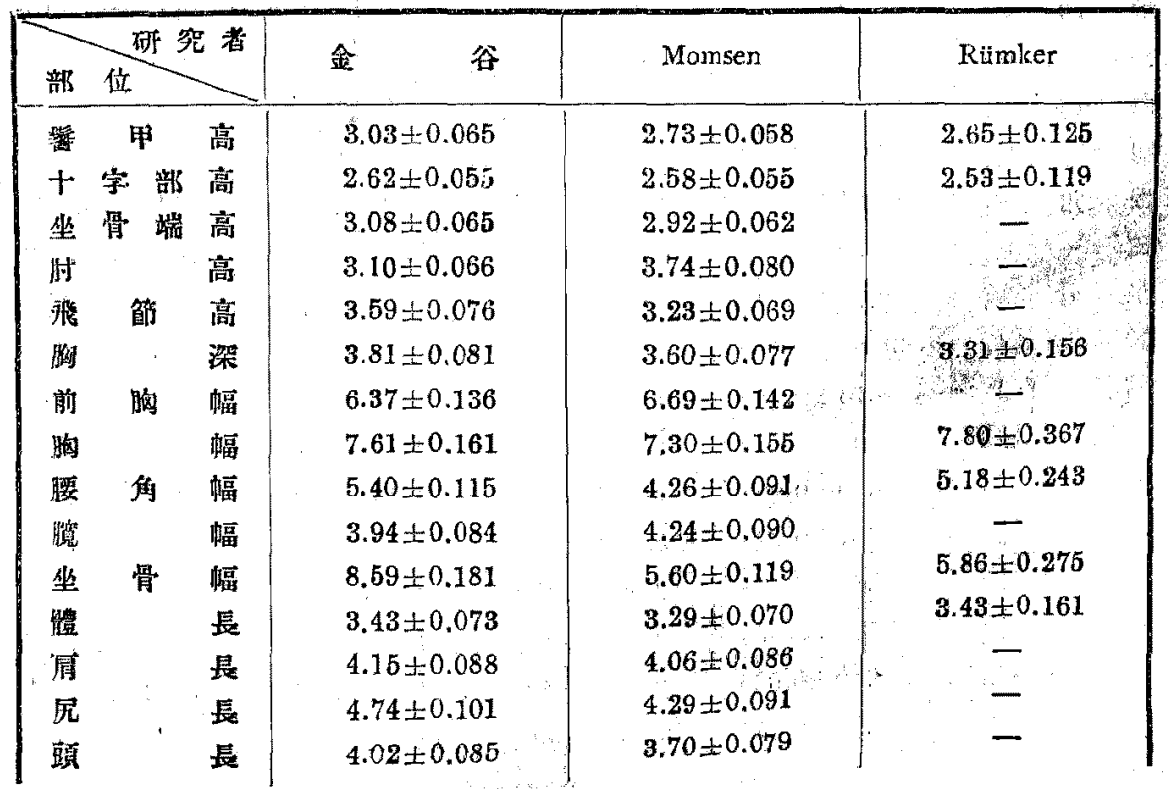




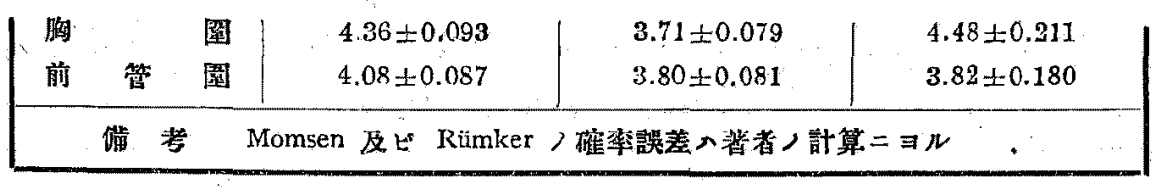

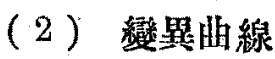

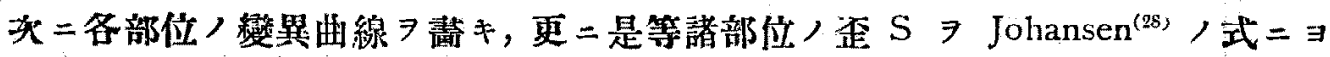
リ，求 $ム ル=$ 馨甲高 +0.30 , 十字部高 +0.14 , 坐骨端高 +0.20 , 肘高 +0.22 , 飛節高 +0.04 , 胸澡 +0.23 , 前胸幅 +0.46 , 胸幅 +0.10 , 腰角幅 +0.07 , 膛幅 +0.28 , 坐骨幅 +0.16 , 體長 +0.72 , 局長 +0.15 , 尼長 +0.25 , 頡長 -0.12 , 胸圍 +0.19 , 前管圍 +0.29 , 後管圍 +0.42 飛節角度一 0.02 , 體重 $+0.31+ル \exists$ 以頭長

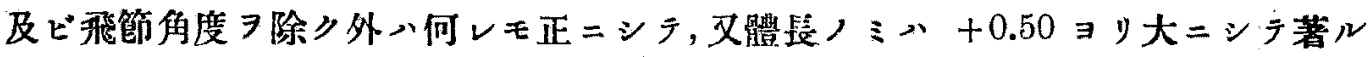
シキ歪ヨナセドモ，其ノ他ノ諸部位、全部 \pm .0 .50 ，範圍內ニアリ，是等ノ內前胸

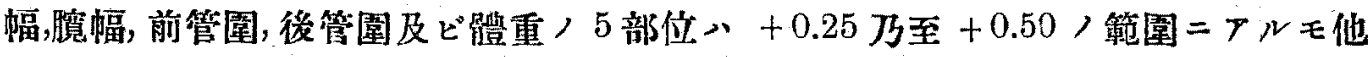
ノ諸部位ニアリラン士0.25ノ範圍內ニアル故ニ小ナル歪ヨナスト言フタ得ベシ。

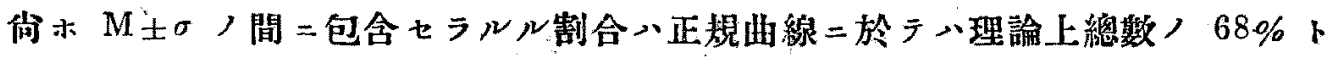

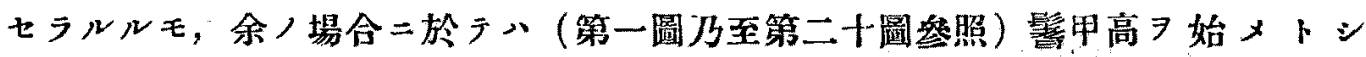
15 部位、 67 万至 $69 \%$ ニテテ, 十字部高, 胸潹, 坐骨幅, 體重ノ 4 部位》 $66 \%$

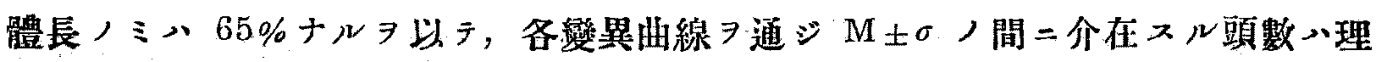
論數・大差ナキガ如シ。

更二各部位ノ變異明線及ビ Quételet ノ正規曲線ノ式ラ求メ之ニョりラ算出七

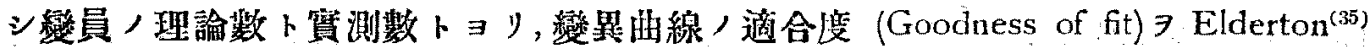

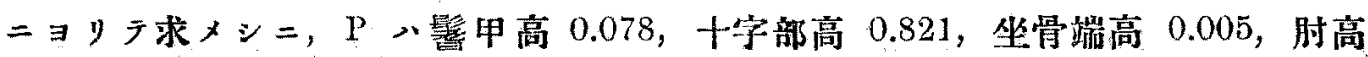
0.006 ，飛節高 0.792 ，胸澡 0.440 ，前胸幅 0.088 ，胸幅 0.653 ，腰你幅 0.507 ，䐸 幅 0.049 ，坐骨幅 0.124，鳢長 0.00002 , 肩長 0.280 , 尼長 0.030 ，頭長 0.062 , 胸圍 0.729, 前管圍 0.004 , 後管圍 0.013 , 飛節争度 0.555 , 體重 0.071 二シテ十字 部高ハ最モヨク適合シ普通ノ材料二於テ1000 頭中 821 頭《適合スル事 ヨ示シ次.

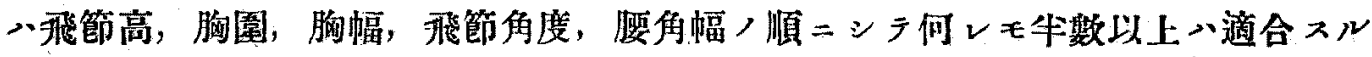

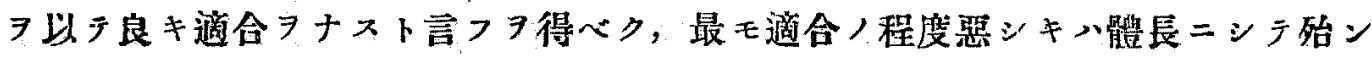

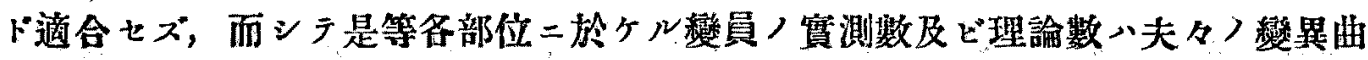
線共二正規曲線 $=ヨ y$ ラ窥知シ得ぶク，且ッ各部位ニッキ是等兩者 $习$ 列學スル事

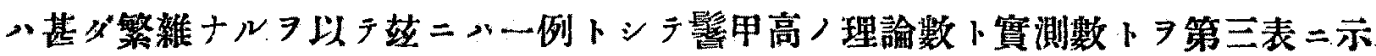




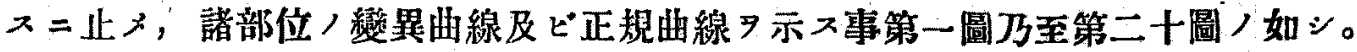
第三表、譬甲高/變異

\begin{tabular}{|c|c|c|c|c|c|c|c|}
\hline \multirow{2}{*}{ 留 } & \multirow{2}{*}{$\underset{\mathrm{cm}}{\stackrel{\mathrm{R}}{\mathrm{C}}}$} & \multicolumn{3}{|c|}{ 紟 } & \multicolumn{3}{|c|}{ 貝 } \\
\hline & & 谓 & 测 政 & $\%$ & & 論 数 & $\%$ \\
\hline & 110.5 & & 19 & 3.8 & & 14.8 & 30 \\
\hline & 112.5 & & 32 & 6.4 & & 39.0 & 7.9 \\
\hline & 114.5 & & 94 & 18.8 & & 75.2 & 15.2 \\
\hline & 116.5 & & 109 & 21.8 & & 106.1 & 21.5 \\
\hline & 118.5 & & 97 & 19.4 & & 108.6 & 22.0 \\
\hline & 1205 & & 82 & 16.4 & & 81.2 & 16.5 \\
\hline & 122.5 & & 37 & 7.4 & & 44.3 & 9.0 \\
\hline & 124.5 & & 19 & 3.8 & & 17.7 & 3.6 \\
\hline & 126.5 & & 8 & 1.6 & & 5.2 & 1.1 \\
\hline & 128.5 & & 3 & 0.6 & & 1.1 & 0.2 \\
\hline & 計 & & 500 & 100.0 & & 193.2 & 100.0 \\
\hline
\end{tabular}

\section{IV 相關係數及ビ回歸方程式}

\section{(1) 二部位間/相關係数}

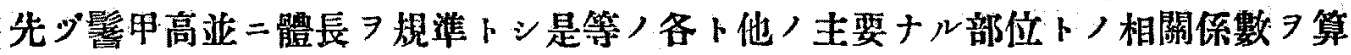
出セシガ，其ノ結果入第四表ニ示スガ如クニシテ何レノ組合セニ於テ毛备相關係

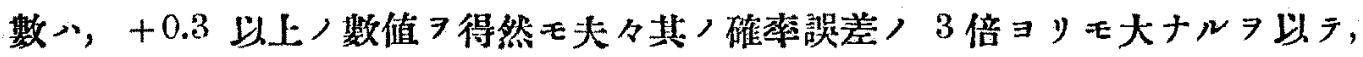
明カ二諸部位間二八正/相關關绿存在ス，而シテ斯/如キ關係入Overbosch ${ }^{(2)}$, 佐々 $木^{(7)}$, Zehnther ${ }^{(8)}$ 等ノ得タル結果ト略ボ一致スル所ナリ, 然レドモ余ノ場合 = 於テメAlpatow 及ビ Boschko-Stepanenko(36) ガ鳥類及ビ魚類等二テ驗シタルが 如キ: Rule of neighbourhood 八適用サレザルガ如シ。

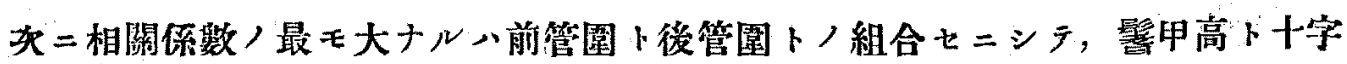
部高卜，場合之二次平，腰角幅卜脫幅，體重卜胸圍等，順ニシテ何レモ+0.75以

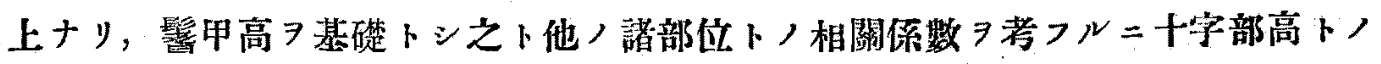
間二於テ最モ大ニシテ胸幅卜ノ間二於テ最モ小ナル事八第五表ニ示スガ如クニシ

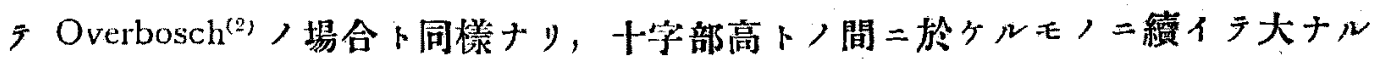
八肘高, 胸深, 體長, 尼屒, 胸圍, 前管圍八順ニシテ是等 7 個 組合七ニ於テン 何 $レ モ+0.5$ 以上ニシテ體重, 腰角幅, 頭長, 胸幅ナル 4 個ノ組合七ニテハ+0.45 乃至 +0.34 八間ニアリ。而シテ篦甲高又心體長卜他八諸部位卜人相關係數、 


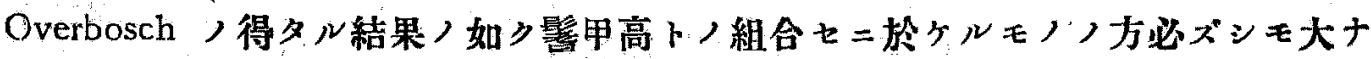

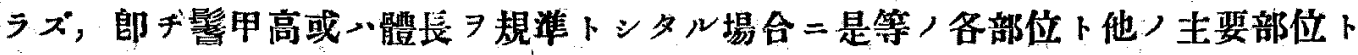

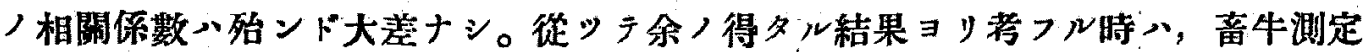

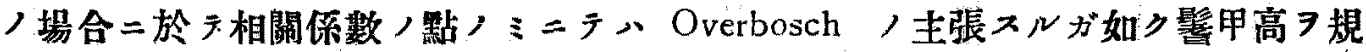

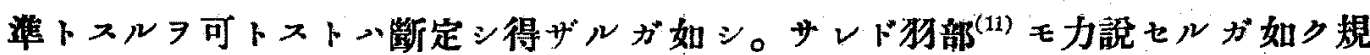

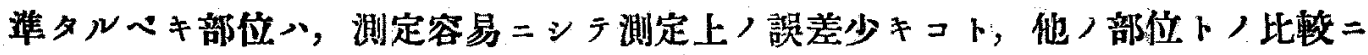
一見便利ナルゴ、，然モ絶對值相當二大ナルコト等/理由及ビ既二余が前述七シ ガ如ク，裝甲高八他ノ部位二比シ變異係數小ナル $ル タ$ 合理的ナリト信ズ。果シナ然りト七心體型ノ標準 7 作成スルニ當り，規淮タ

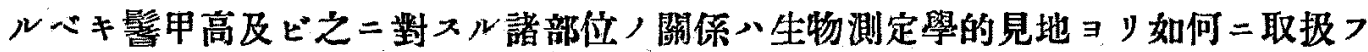

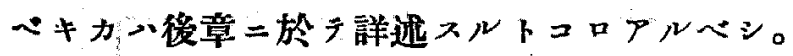

Zimmer ${ }^{(27)}$ 八管圍ト骨ノ大小トノ間二密接ナル關係ノ存在スル事 7 論シ，佳々

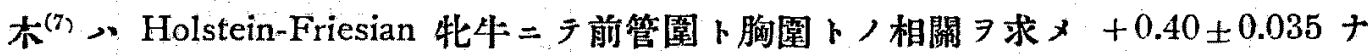

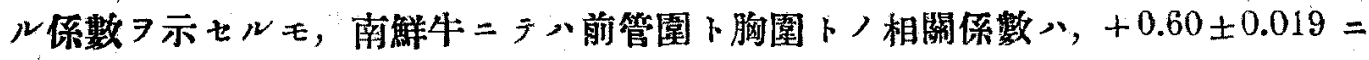

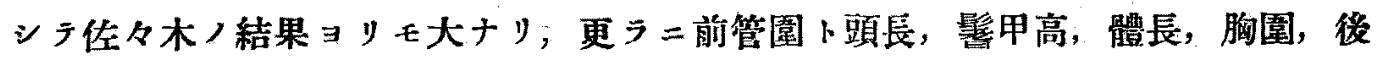

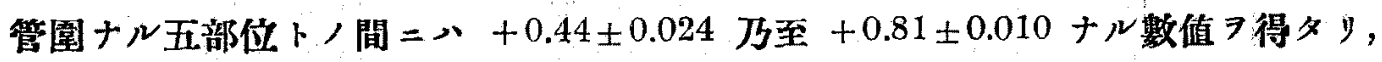

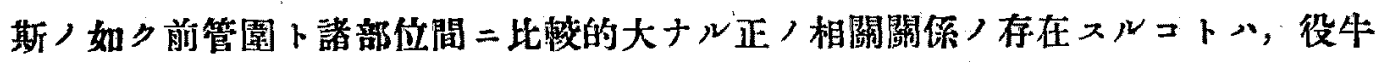
タル朝鮮牛二於テハ鑑定上特二考慮习要スル點ナり。

第 四表 相關係數表(其一)

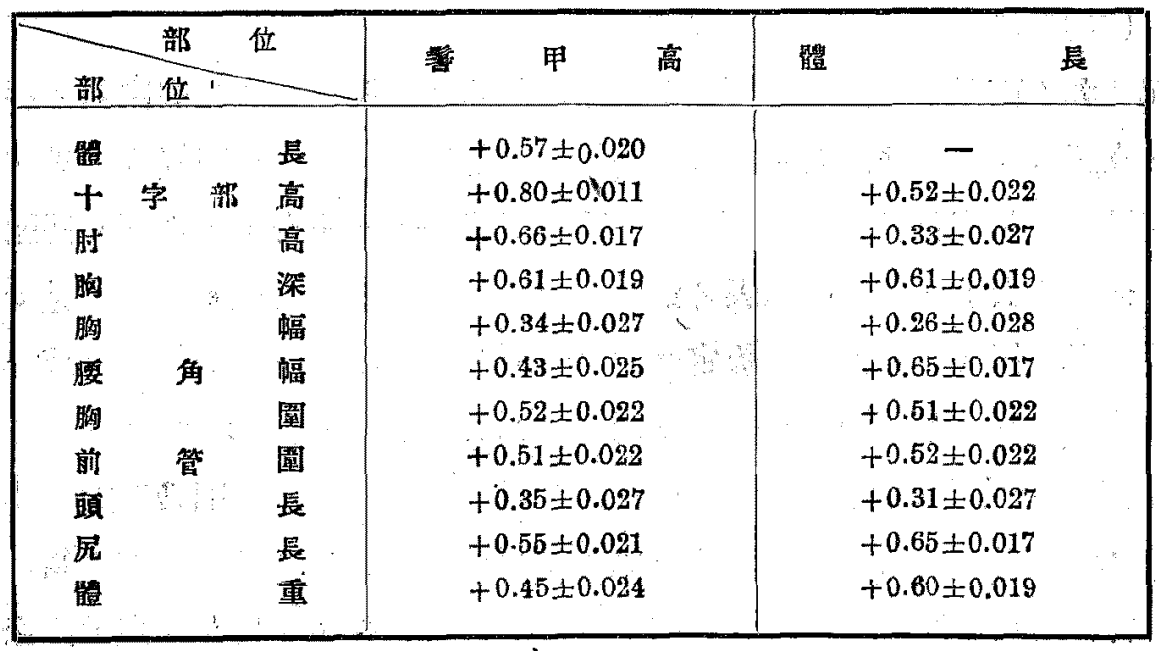




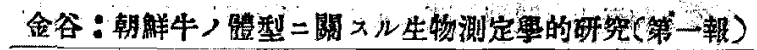

第四表 相關俰數表（其二）

\begin{tabular}{|c|c|c|c|c|c|c|c|c|c|c|}
\hline & 相 & 閭 & & 部 & 位 & & 相 & 閣 & 係 & 新 \\
\hline 时 & & 高 & F & 㱟 & 節 & 高 & \multicolumn{4}{|c|}{$+0.61 \div 0.019$} \\
\hline 棜 & & 高 & F & 肩 & & 長 & \multicolumn{4}{|c|}{$+0.42 \pm 0.025$} \\
\hline 腰 & 出 & 幅 & 1 & 胸 & & 幅 & \multicolumn{4}{|c|}{$+0.48 \pm 0.023$} \\
\hline 腰 & 角 & 幅 & 下 & 瞳 & & 幅 & \multicolumn{4}{|c|}{$+0.76 \pm 0.013$} \\
\hline 腰 & 角 & 幅 & 1. & 屁 & & 長 & \multicolumn{4}{|c|}{$+0.64 \pm 0.018$} \\
\hline 前 & 管 & 園 & $\mathbf{r}$ & 胸 & & 圍 & \multicolumn{4}{|c|}{$+0.60 \pm 0.010$} \\
\hline 前 & 管 & 圍 & F & 後 & 管 & III & \multicolumn{4}{|c|}{$+0.81 \pm 0.010$} \\
\hline 前 & 管 & 图 & N & 頙 & & 長 & \multicolumn{4}{|c|}{$+0.44 \pm 0.024$} \\
\hline 胸 & & 園 & $r$ & 體 & & 重 & \multicolumn{4}{|c|}{$+0.75 \pm 0.013$} \\
\hline
\end{tabular}

第五表 相關你數比僌表

\begin{tabular}{|c|c|c|c|c|c|c|c|c|}
\hline \multicolumn{7}{|c|}{ 相關部位 研 究 者 } & 金 & \\
\hline 䈠 & 甲 & 高 & r & +5 & 部 & 高 & $+0.80 \pm 0.011$ & $+0.96 \pm 0.002$ \\
\hline 䇾 & 甲 & 高 & $\uparrow$ & 肘 & & 高 & $+0.66 \pm 0.017$ & - \\
\hline 謷 & 甲 & 高 & 卜 & 胸 & & 深 & $+0.61 \pm 0.019$ & $+0.51 \pm 0.021$ \\
\hline 譬言 & 甲 & 高 & r & 胸 & & 䒇 & $+0.34 \pm 0.027$ & $+0.26 \pm 0.029$ \\
\hline 䇾 & 甲 & 高 & p & 腰 & 筩 & 楅 & $+0.43 \pm 0.025$ & $+0.46 \pm 0.023$ \\
\hline 謷 & 甲 & 高 & r & 體 & & 曼 & $+0.57 \pm 0.020$ & $+0.49 \pm 0.022$ \\
\hline 敏 & 甲 & 高 & F & 胸 & & 图 & $+0.52 \pm 0.022$ & $+0.58 \pm 0.020$ \\
\hline 䇾 & 甲 & 高 & F & & 管 & 圈 & $+0.51 \pm 0.02 \mathrm{~g}$ & $\therefore \quad-$ \\
\hline 笪祒 & 甲 & 高 & ト & 頍 & & 長 & $+0.35 \pm 0.027$ & - \\
\hline 警 & 甲 & 高 & r & 尼 & & 唇 & $+0.55 \pm 0.021$ & - \\
\hline 箁 & 甲 & 高 & 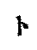 & 锩 & & 長 & $+0.45 \pm 0.024$ & - \\
\hline
\end{tabular}

(2) 二部位間,回歸方程式

前記ノ如り南鮮牛二於ケル外貌上ノ諸部位間二メ明二正ノ相關關係ノ存在スル

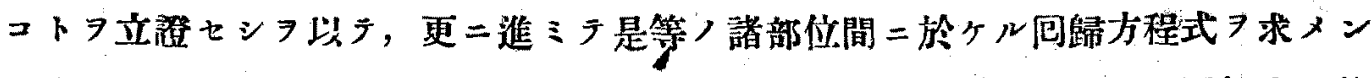

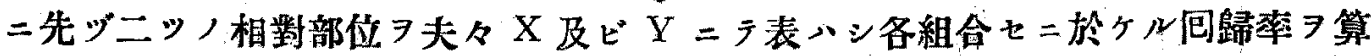
出シ一括シラ表示スレバ第六表ノ如シ，次二各部位，本均價及ビ夫タ是レ二該當 スル包歸率 7 㨉入シ方程式 $フ$ 算定スルコト第七表ノ如シ（各回歸率入或部位一單

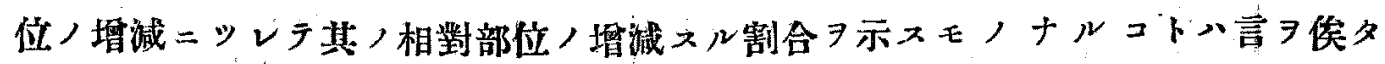
ズ)。是等ノ各方程式二於ラ何レカ一力，任澺ノ數值（第一圖乃至第二十圖二示

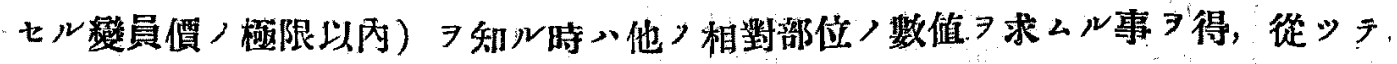

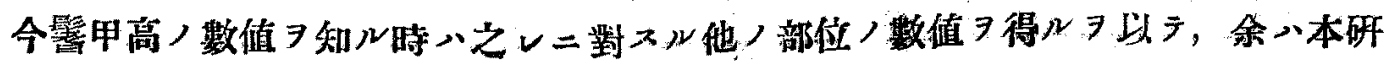




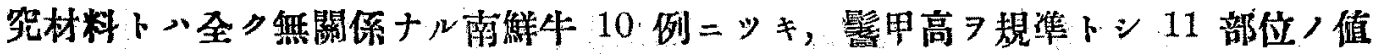

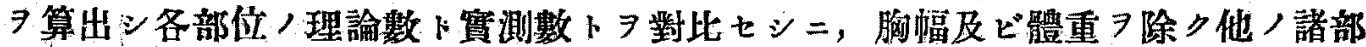

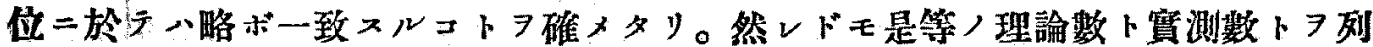

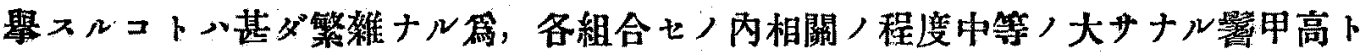
體長トノ場合ニッキテ一例テ擧ダレバ第入表ノ如シ。

第亲表回歸雮

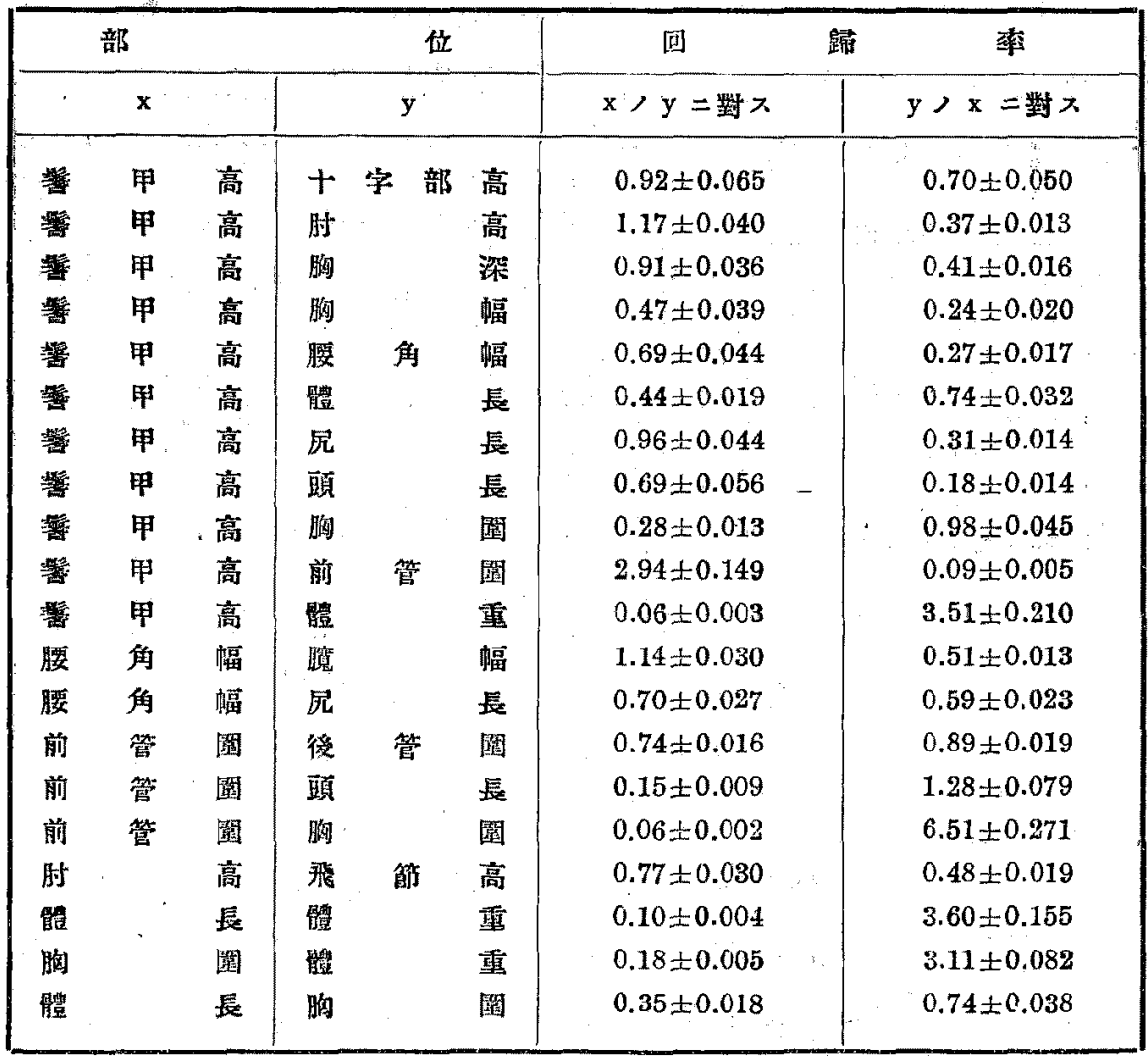

第 七 表 问歸方程式

籍甲高 $X$, 十字部高 $Y$

$f X=0.92 Y+8.44$

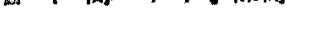

$\{Y=0.70 X+36.36$

等甲高 $\mathrm{X}$, 封高 $\mathrm{Y}_{1}$

$\left\{X=1.17 Y_{1}+41.87\right.$

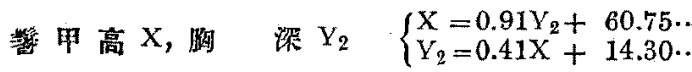

$X=0.91 Y_{2}+60.75$

淽甲高 $\mathrm{X}$, 胸、幅 $\mathrm{Y}_{3}$

$\left\{\mathrm{X}=0.47 \mathrm{Y}_{3}+101.79\right.$..

留里高 $\mathrm{X}$, 腰角幅 $Y_{4}$

$\left\{\begin{array}{l}X=0.69 Y_{4}+89.20 \\ Y_{4}=0.27 X+9.47\end{array}\right.$ 
紫甲高 $\mathrm{X}$ ，體晨 $\mathrm{Y}_{5} \quad \mathrm{X}=0.44 \mathrm{Y}_{5}+57.96 \ldots \ldots \ldots \ldots \ldots \ldots$ (11)

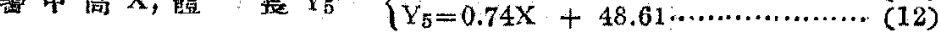

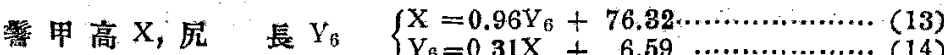

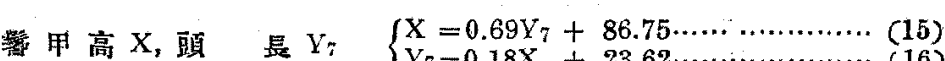

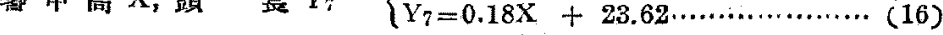

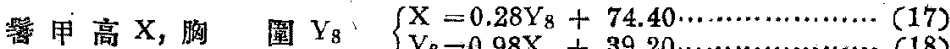

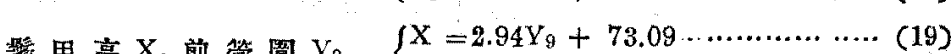

标电高X, 前管園 $\mathrm{X}_{9} \quad \mathrm{Y}_{9}=0.09 \mathrm{X}+4.59 \ldots \ldots \ldots \ldots \ldots$ (20)

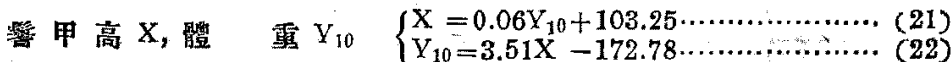

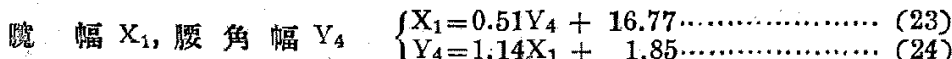

飛穊高 $\mathrm{X}_{2}$, 肘 高 $\mathrm{Y}_{1} \quad\left\{\mathrm{X}_{2}=0.48 \mathrm{Y}_{1}+13.15 \ldots \ldots \ldots \ldots \ldots(25)\right.$

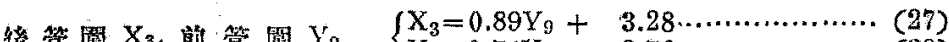

後管圈 $\mathrm{X}_{3}$ ，前管圈 $\mathrm{Y}_{9} \quad\left\{\mathrm{Y}_{9}=0.74 \mathrm{X}_{3}+2.76 \ldots \ldots \ldots \ldots \ldots \ldots\right.$ (28)

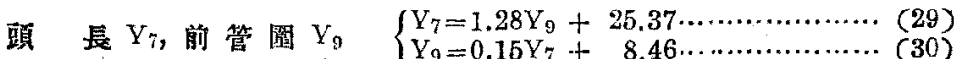

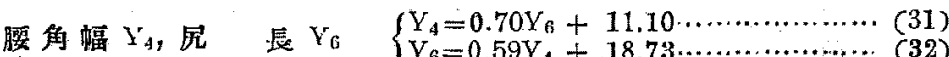

$\left\{Y_{6}=0.59 Y_{4}+18.73 \ldots \ldots \ldots \ldots \ldots \ldots\right.$ (32)

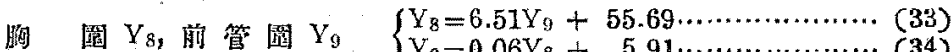

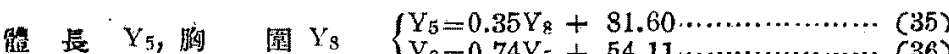

$\left\{Y_{8}=0.74 Y_{5}+54.11 \cdots \cdots \cdots \cdots \cdots \cdots(36)\right.$

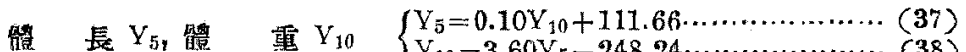

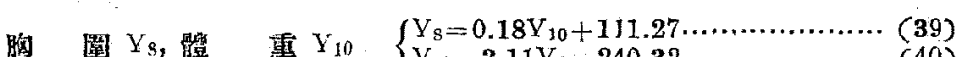

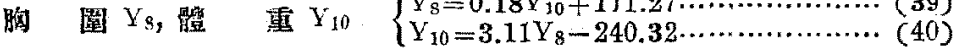

第 八 表 體長ノ理論數卜實測數

\begin{tabular}{|c|c|c|c|c|c|}
\hline \multirow{2}{*}{ 番號 } & \multirow{2}{*}{ 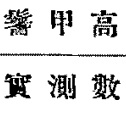 } & \multicolumn{2}{|c|}{ 䯣 } & \multicolumn{2}{|c|}{ 長 } \\
\hline & & 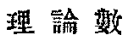 & 䈨 测 数 & 差 & $\%$ \\
\hline 1 & $111 \cdot 0$ & 130.8 & 127.0 & -3.8 & 2.9 \\
\hline 2 & 112.1 & 131.6 & 131.5 & -0.1 & 0.1 \\
\hline 3 & 113.0 & 132.2 & 129.0 & -3.2 & 2.4 \\
\hline 4 & 114.0 & 133.0 & 128.0 & -5.0 & 3.8 \\
\hline 5 & 115.0 & 133.7 & 134.0 & +0.3 & 0.2 \\
\hline 6 & 116.0 & 134.5 & 134.0 & -0.5 & 0.4 \\
\hline 7 & 118.0 & 135.9 & 137.5 & +1.6 & 1.2 \\
\hline 8 & 122.0 & 138.9 & 141.5 & +2.6 & 1.9 \\
\hline 9 & 127.0 & 142.6 & 147.0 & +4.4 & 3.1 \\
\hline 10 & 128.5 & 143.7 & 149.5 & +5.8 & 4.0 \\
\hline
\end{tabular}




\section{$\boldsymbol{V}$ 標 準 體 型}

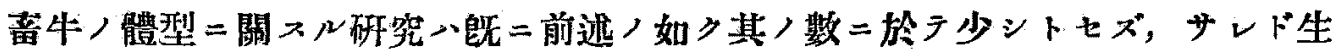
物測定學的見地ヨリ體型ノ䅺準ヨ示シタル業績二至リテメ殆ンド之レ無キが如 シ, 殊二蓄牛，體型 7 改艮シ吾人ノ理想トスル所ニ近ヅカシメントスルニ當リラ

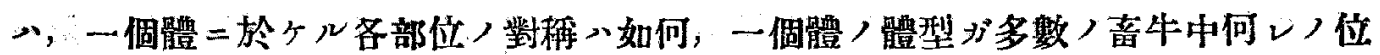
置ニアルカ，又個體トシテモ或ハ一地方二於ケル倜體群トシテモ，其，體型ガ他地 方ノモノ又心他，品種卜比转シラ綜合的二如何ナル關係ニアハカラ知ルハ榷メテ 必要ナルコトナリトス，即チ一音牛二於其ノ各部位ノ大サ八多數，同品種〉畜

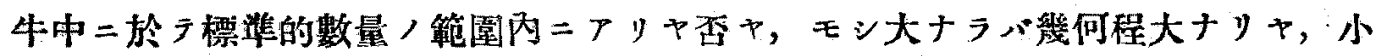

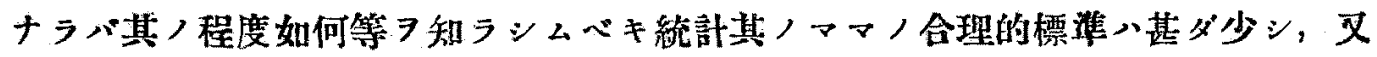

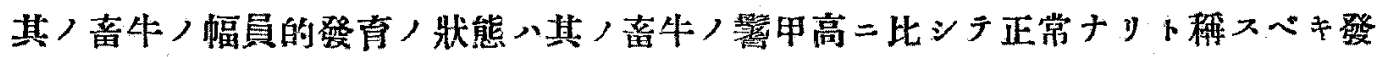

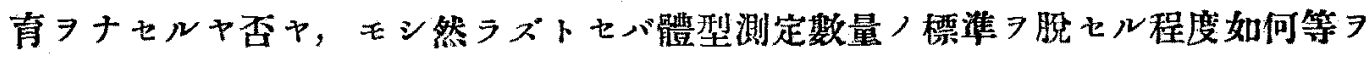

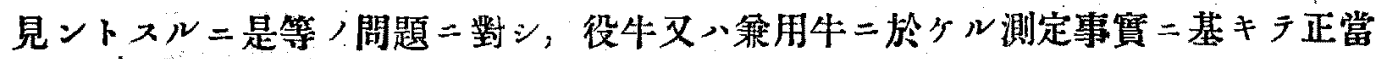
二答へシムル研究ハーモ存在セザルナリ。是レガ第從來行ハレタル體型測定二於 ケル効果ノ減殺セラレタルコト少ナカラザルベ。经二於テ如上ノ缺陷ヨ充サン

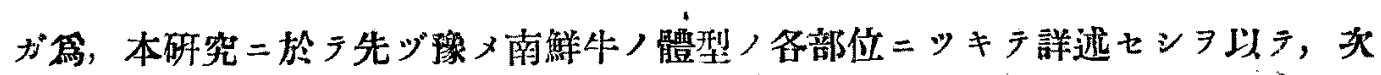
二余ノ测定ノ結果二理想 $コ$ 加フル矛ナク統計其ノママノ數量ニヨル正常體型 $フ$ 算 定スル事ハ，他品種卜雜㮔蕃殖 良セントスル南鮮生 ${ }^{(38)}$, 場合二於テハ特二重大ナル事項ナルバシ。

Rautmann (33) ${ }^{(3)} 1921$ 年二人類 體型二關入从研究二於テ生物测定學的見地

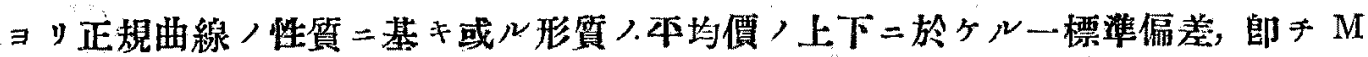
十 $\boldsymbol{\sigma} \mathrm{M}-\boldsymbol{\sigma}$ 卜ノ間二於ヶル總テノ大サ

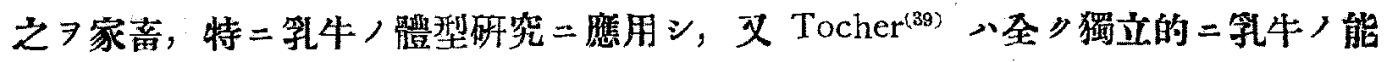
才二關ス几研究二於チ之ト略ホ同㧼ナル方法ヨ探用セり。余心前迅〉如ク外貌榙 部位間 於ヶ $2 \mathrm{M} \pm \sigma$ ，範園二八總頭數ノ65 乃至 $69 \%$ (第一圖乃至第二十圖参照) 包

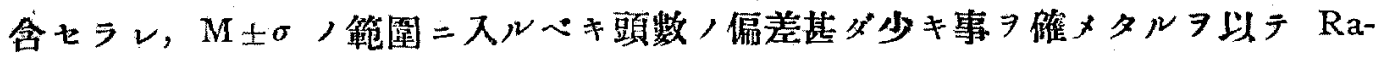
utmann ${ }^{(33)}$ ）方法 7 應用シ南鮮牛ノ正常體型ヨ定メントス。

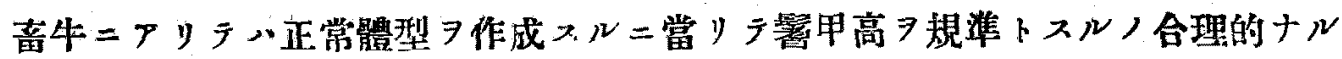

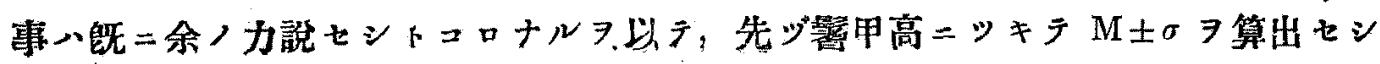


二第一圆ニ示スガ如ク，其ノ範圍二。總頭數， $69 \%$ 即チ 345 頭 7 包含セラルル ヌトヨ確メタリ，次二今得タル 345 䫑 體長，胸深，胸幅，腰角幅，尻長，胸圍，前管圍等二於テ夫タノ $\mathrm{M} \pm \sigma \ni$ 算定シ表

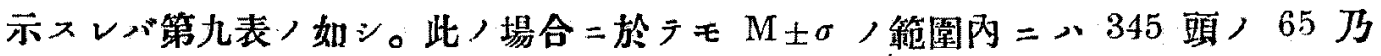
至 $69 \%$ ７包含七ラレ，總頭数 500 頭二對シテハ 45 乃至 $47 \%$ =相當ス, 余》 斯クシテ得タル正常體型（Normal type）師于諸部位，M- $\mathrm{M}$ 乃至 $\mathrm{M}+\sigma$ 綜合

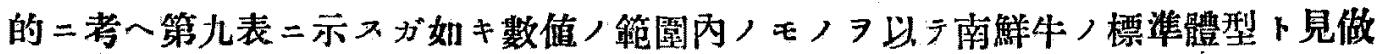

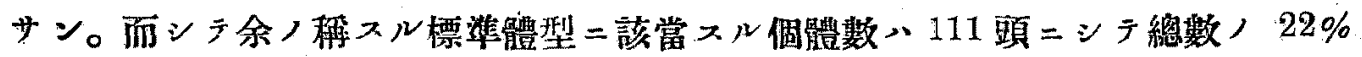
二當ル事ヨ確メタリ。此ノ標準體型 (Standard type) 入既= Holstein-Friesian 程

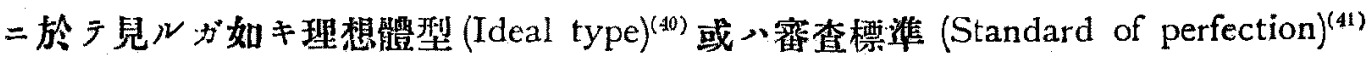
ノ作成，マタ體型繿定上基ダ重要ナル参考資料タルベシ。

第 九 表 正 常 體 型

\begin{tabular}{|c|c|c|c|c|c|}
\hline 部 & & 位 & $(M-\sigma)-(M+\sigma)$ & 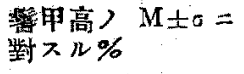 & 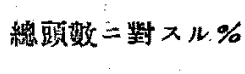 \\
\hline 篦 & 甲 & 高 & $114-121$ & 100 & 69 \\
\hline 脑 & & 溧 & $60-64$ & 68 & 47 \\
\hline 胸 & & 幅 & $31-36$ & 69 & 47 \\
\hline 腰 & 角 & 楅 & $39-43$ & 66 & 45 \\
\hline 體 & & 長 & $131-139$ & 65 & 45 \\
\hline 层 & & 震 & $41-45$ & 67 & 46 \\
\hline 胸 & & 图 & $148-160$ & 67 & 46 \\
\hline 前 & 管 & 圍 & $15-16$ & 65 & 45 \\
\hline
\end{tabular}

\section{VI 摘 要}

1. 體型ノ優良ナル5 歳以上/南鮮此牛 500 頭 19 部位及ビ體重ニッキテ夫タ生物测定學的恒數习泳メ，少亦體表面皘

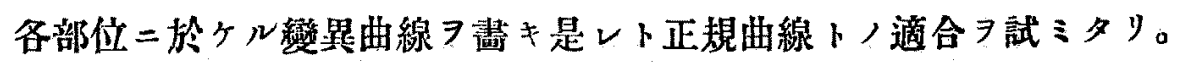

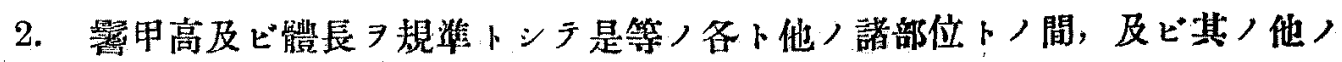
諸部位相互間二於テモ常二正，相關關嗤，存在スルントヨ立證シ，更二各部位間 ノ问歸萃及ビ包歸方程式 7 算定セり。

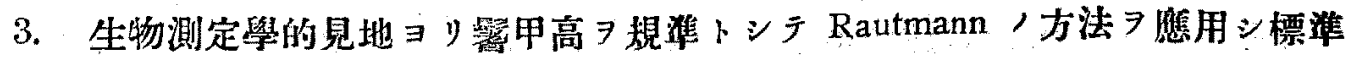
體型 $\ni$ 作成セ少。 


\section{文獻}

(1) Zorn, W., Die Anwendung der Ausgleichsrechnung u. Vạiationsstatistik auf Rindermessungen mit besanderer Berucksichtigung des Glatzer Gebirgsviehes. Mitt. d. Landw. Institute d. Univ. Breslau, Bd VI, Heft. 4, Berlin 1911. (2) Overbosch, H. W, Statistische Studien über Rinderbeurteilung nach den Körpermassen. Diss. Bern. 1912. (3) Augustin, E, Über Korrelation zwischen Kö̈rperform u. Milchleistung. Diss. Bern. 1913. (4) Brun, J., Studium uber biometrik u Vererbung des Milchspiegels bei der Kuh Jahrb. wiss. 4. prakt. Tierzucht. Jahrg. XV, 1922. (5) Feige, E, Variationsstatistische Untersuchungen an Haustieren. Fiuhlungs Landw. Zeitung. Jahrg LXX, Heft 13/14, 17/18, 19/20, 1921. Jahrg. LXXF, Heft 19/20, 1922. (6) Gogen, J. W., Conformation and its relation to milk producing capacity in Jersey cattle. Jour. Dairy, Sci, . Vol, III, No. 1, 1920. , Studies on conformation in relation to milk producing capacity in cattle. Jour. Agric. Res., Vol. XXX, No. 9, 1995. (7) Sasaki, K, Biometric study of form in the Holstein-Friesian cow. Jap. Jour. Zootechn. Sci, Vol. II, No. 3, 1927. ____, On the determination of a norm for the dairy cow. Ibid., Vol. III, No. 3, 1928. (8) Zehntner, L, Kritische biometrische Mesşungen an den Schweizerrinderrassen. Diss. Bern 1917. (9) Bartlett, S, Variation in the live weight of daiy cows. Jour. Agric. Sci., Vol. XVI, Pt. 3, 1926.

The effect of pregnancy on the live weight of dairy cows. Ibid. (10) Gaude, W, Die Beziehungen zwischen Körperform u. Leistungen in der Rindviehzucht. Arb d Deul. Gesellsch.

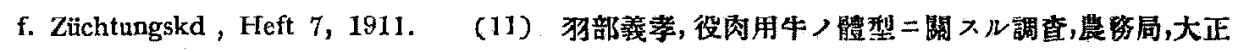

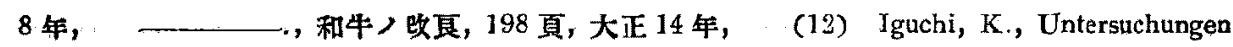
über die japanischen Boviden. Jour. Coll. Agric., Hokkaido Imp. Univ., Sapporo. Vol. IX, Pt. 5, 1920. (13) Konopinski, T., Beitrag zur liestimmung des Verhaltnisses zwischen Widerristhöhe u. Brusttiefe sowie Beinhöhe bei Jungbullen. Zeits. f. Tierzücht. u. Ziichtungsb,

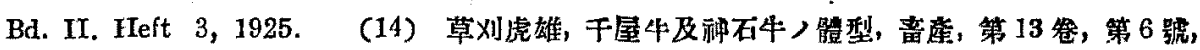
昭和 2 年. (15) Liebetrau, O., Variationsstatistische Untersuchungen über Form u. I eistung an Kühen der schwarzbunten Niederungsrasse der Stamzuchtgenossenschaft Eutin. Diss. Halle 1927. (16) Lush, J. L, The accuracy of cattle weights. Jou. Agric. Sci., Vol. XXXVI, No. 6, 1928. (17) Mittelstaedt, H. H., Studiem am schwarzweissen ostpreussischen Tieflandrind unter besonderer Berucksichtigụng der Korrelation zwischen Körperform u. Milchleistung. Diss. Halle 1926. (18) Momsen, C., Typveränderung der ostfriesischen Milchkuh. Arb. d. Deut. Gesellsch. f. Züchtungskd, Feft 33, 1926. (19) 荻野周次, 乳牛ノ謷甲高卜十学部

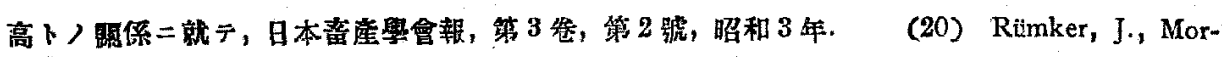
phologischee Untersuchungen an in Deutschland gezogenen Shorthornrindern. Landw. Jahrb.,

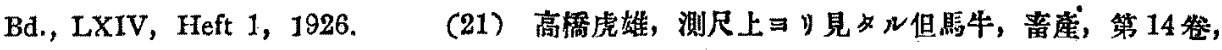
第 8 號，昭和 3 年. (22) Todorovic, S., Biometrische Studien iiber das Wachstım weiblicher Pinzgauer u. Murbodener Rinder. Diss. Bern 1913. 


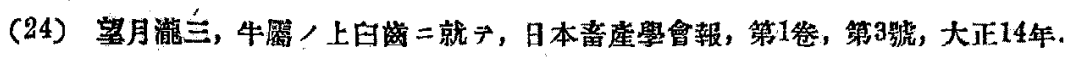

東方亞細亞二於々儿家湆牛，系統的研究，同上，算 2 卷，第 4 號，昭和 2 年.”一，䏩

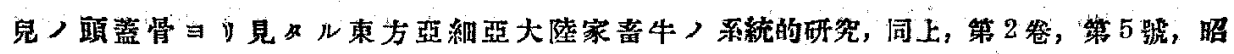

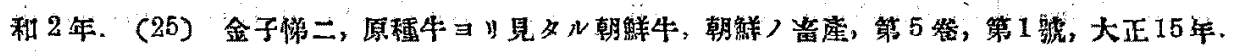
(26) Pusch-Attinger, Beurteilung des Rindes, Aufl. 3, S. 112-114, 116-120, 140-141, Berlin 1923: (27) Hansen, J, Lehrbuch der Rindexzucht, S. 67-70, Berlin 1921. (28) Lang, A., Experimentelle Vererbungslehre in der Zoologie zeit 1900, S. 322, 460-464, Jena 1914. (29) 小會金之助, 統計的听究法, 第 5 版, 昭和 2 年. (30) Riet $z, I I . L$, Itandbook of matheratical statistics, P. 77, New York 1924. (31) Yasukawa, K, On the probable error of the mode of skew frequency distributions. Biometrika, Vol, XVIIr, Pts. 3 \& 4, 1926. (32) Baner, J, Der jetzige Stand der Lehre von, der Konstitution. Deut. Mediz. Wcher., Jahrg. XIVI, Nr. 14/15, 1920. (33) Rautmann, H, Untersuchungen über dié Norm, ihre Bedeutung u. Bestimmung, Jena 1921. (34) Elting, E. C., A formula for estimating surface area of dairy cattle. Jour. Agric. Res,, Vol, XXXII, No. 3, 1926. Elderton, W. P., Tables for testing the goodness of fit of theory to observation. Biometrika, Vol. I, No. 2, 1902. (36) Alpatov, W. W., and Boschko-Stepanenko, A. M., Variation and correlation in sirially situated organs in insects, fishes and birds. Amer. Nat, Vol. LXII, No. 682, 1928. (37) Zimmer, A., Untersuchungen über den Wert der Sehienbeinmessungen zwecks Feststellung der Knochenstärke Zeits. f. Tíerzücht. ì. Züchtungsb, Bd. IX, Heft 2,

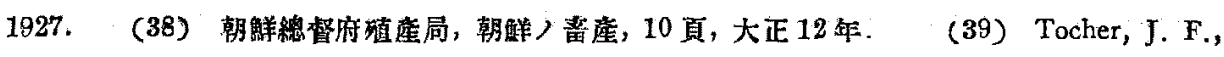
An investigation of the milk yield of dairy cows. Biometrika, Vol. XXB, Pt. 2, 1928 (40) Megargee, S. E, and Kawamura, $G$, The ideal dairy cow. Cited by Gulliver, H. G. in the Holsteir-Friesian World, Vol. XXIII, No. 17, 1926. (41) Plumb, C. S., Judging , farm animals, Pp. 330-334, New York 1928. 
第一圖警甲高

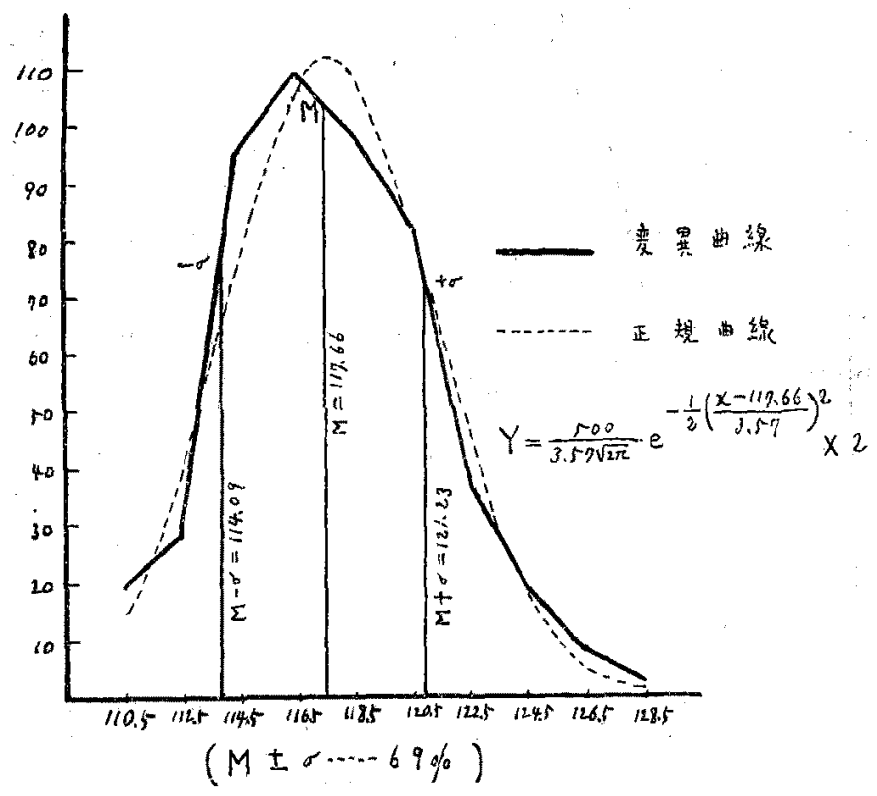

第二圖十字部高

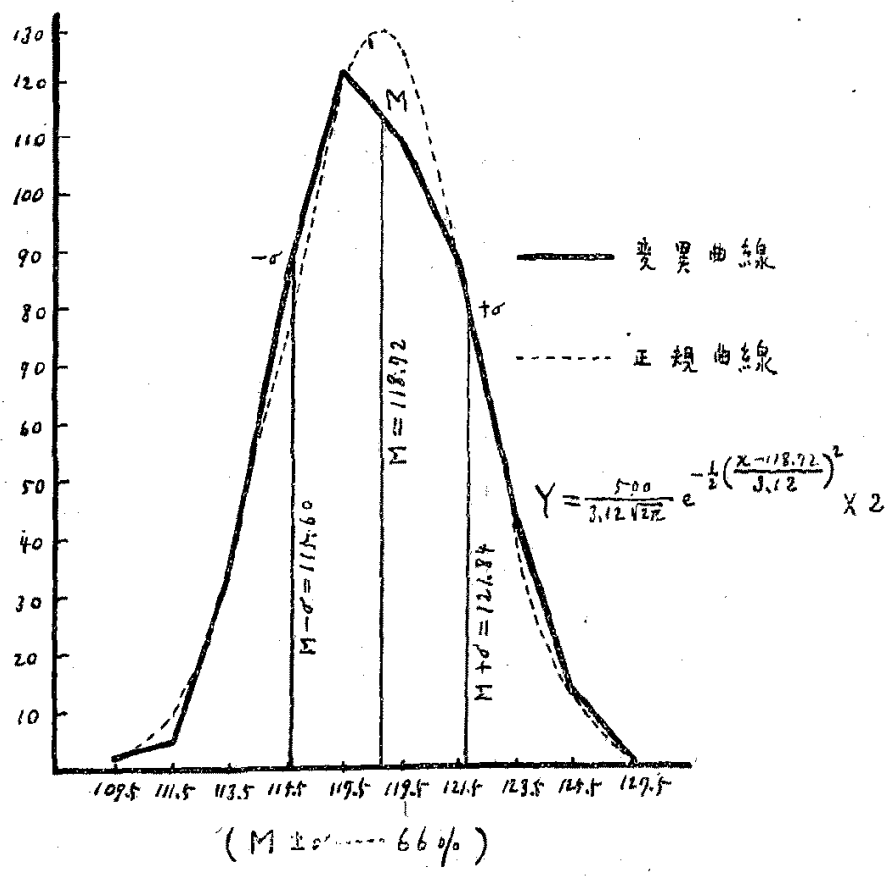


第三圖 坐骨端高

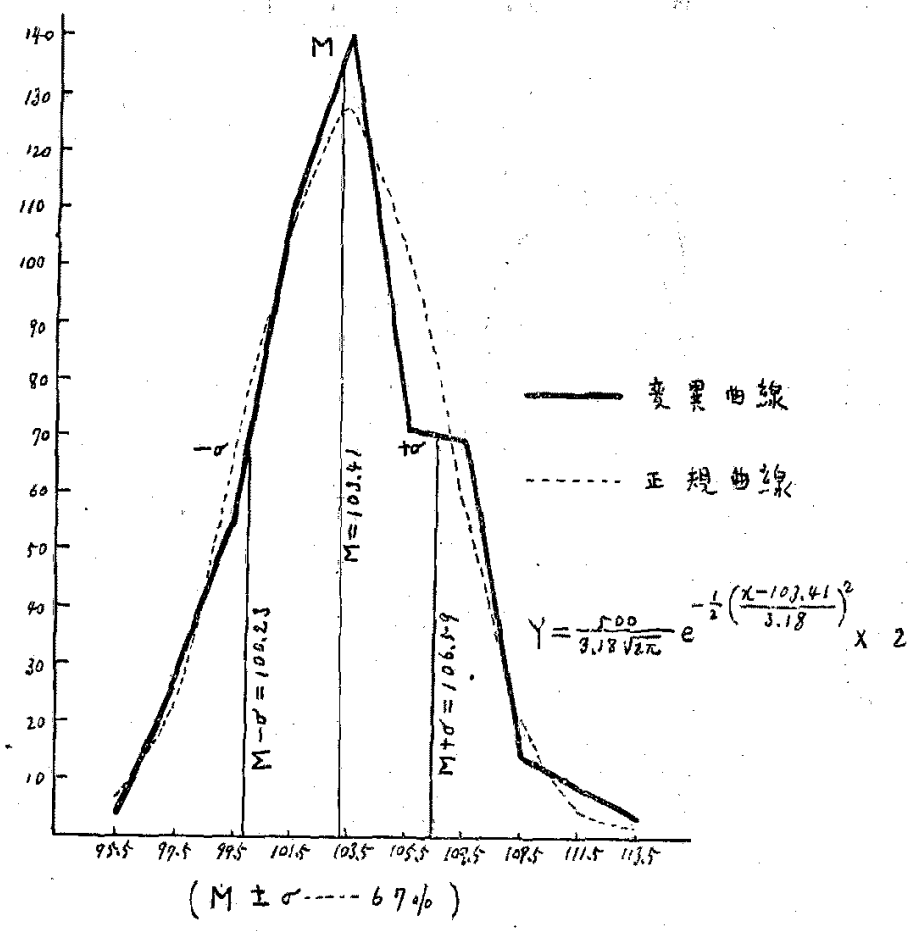

第四圖肘高

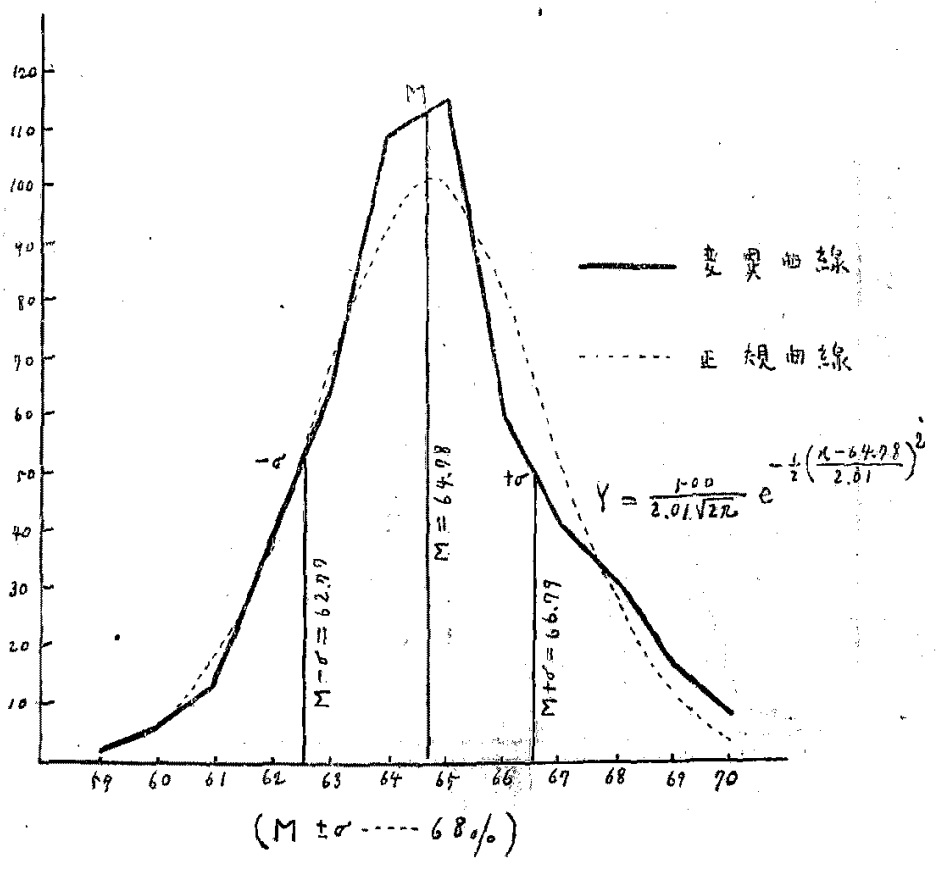


第 王 圖 飛節 高

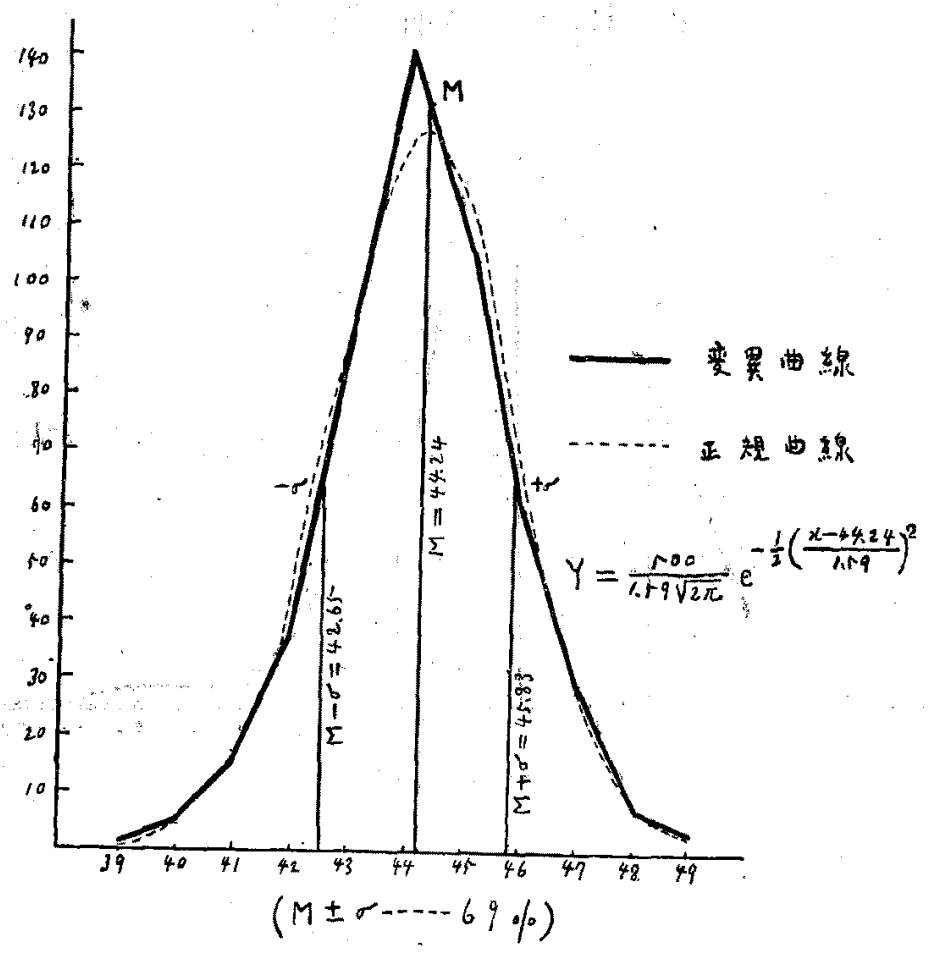

第六圆胸深

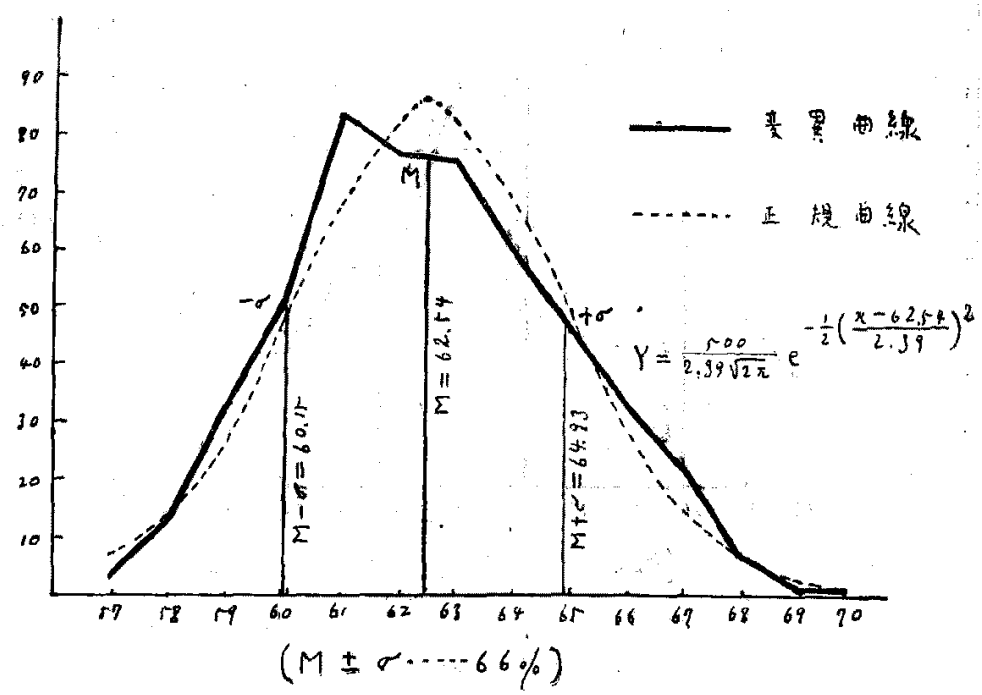


第七圆:前䐱幅

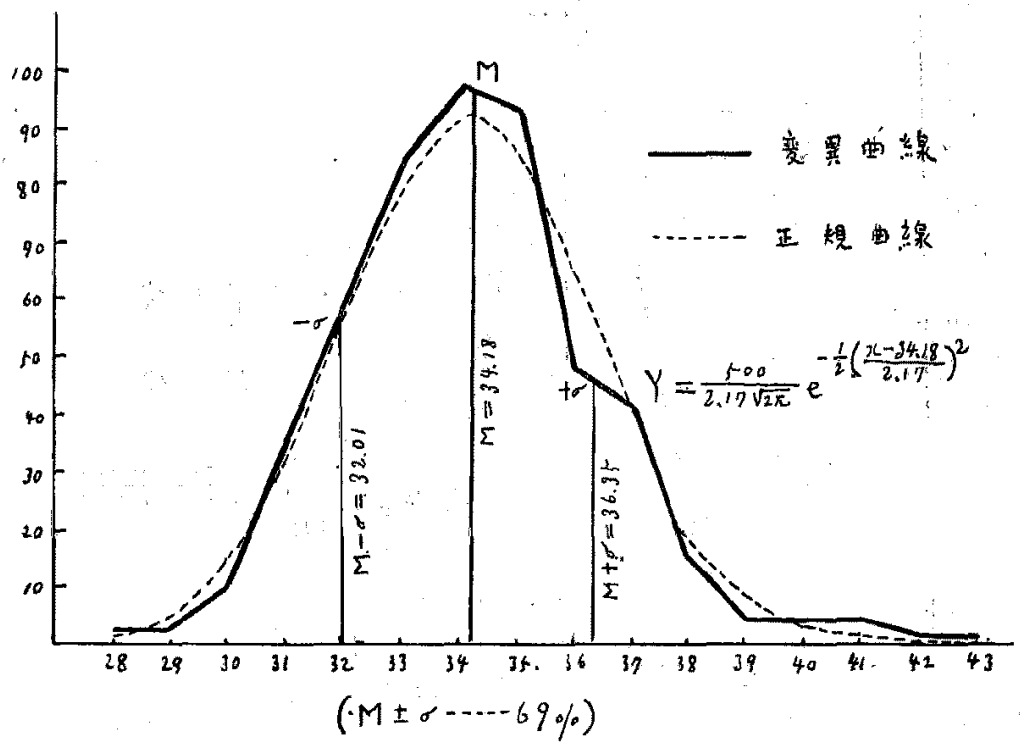

第入圖胸輻

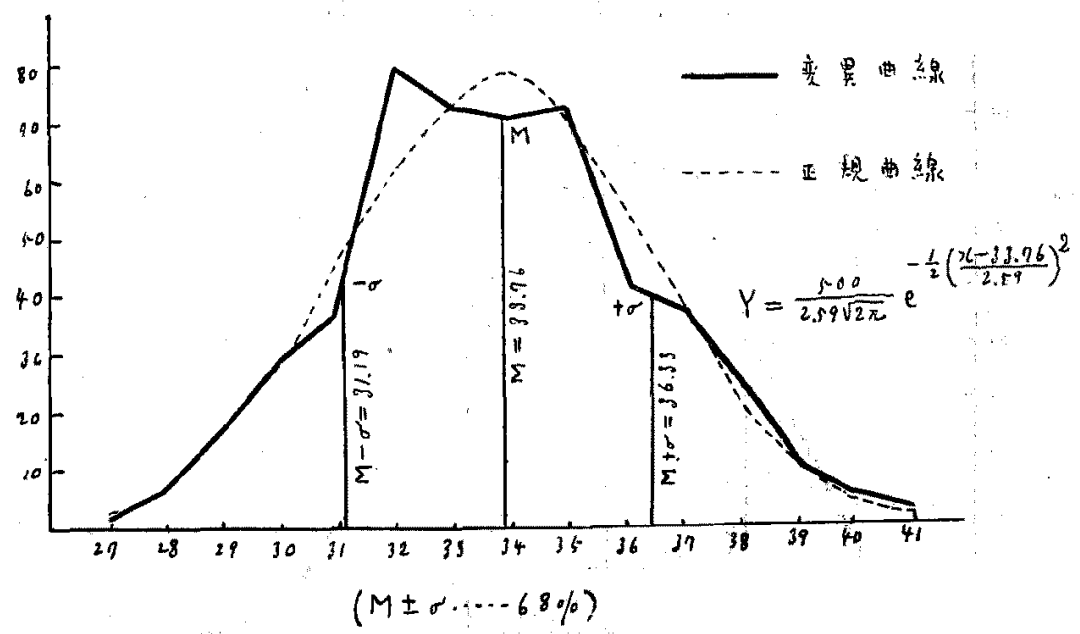


第九圖腰角幅

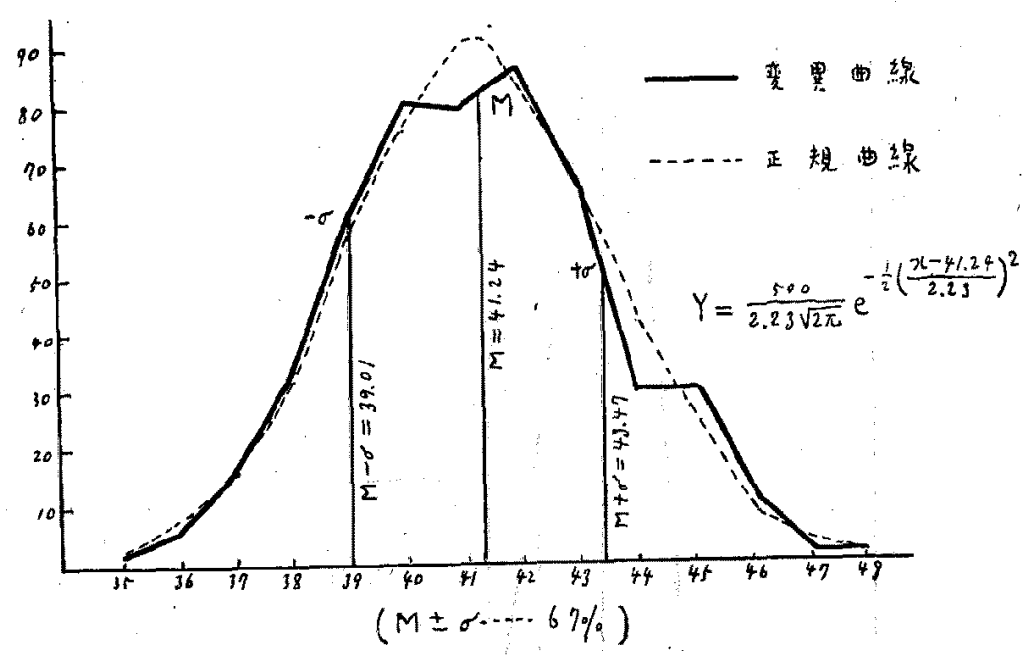

第十圖覫幅

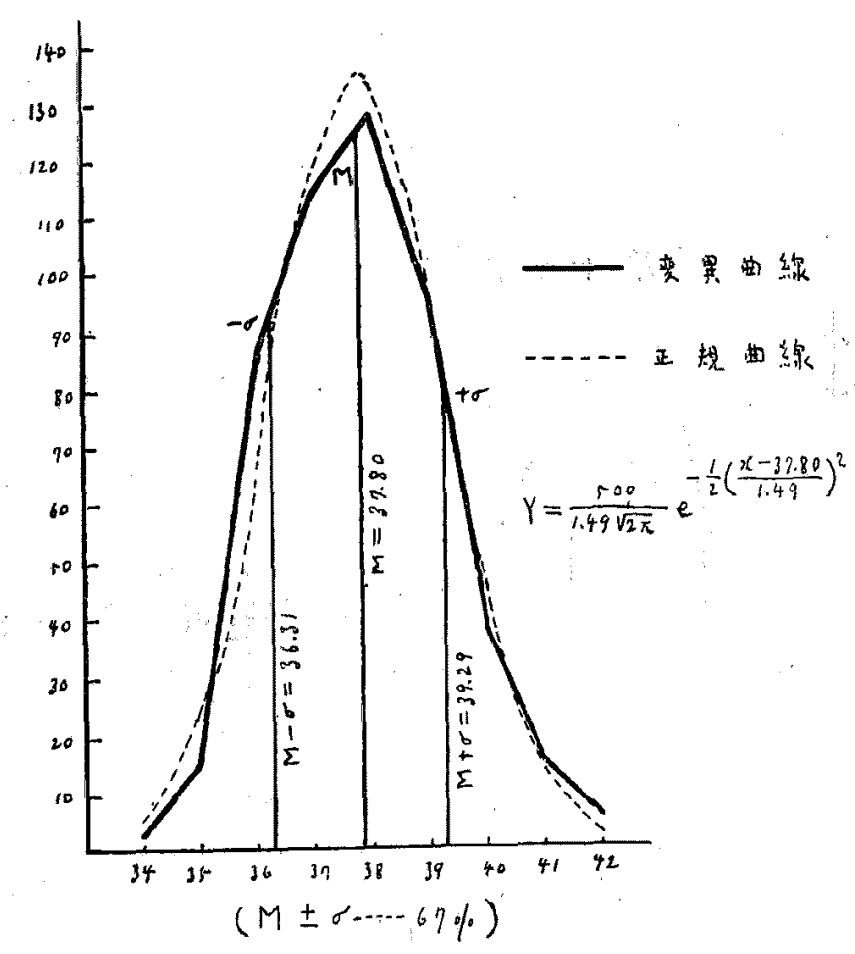



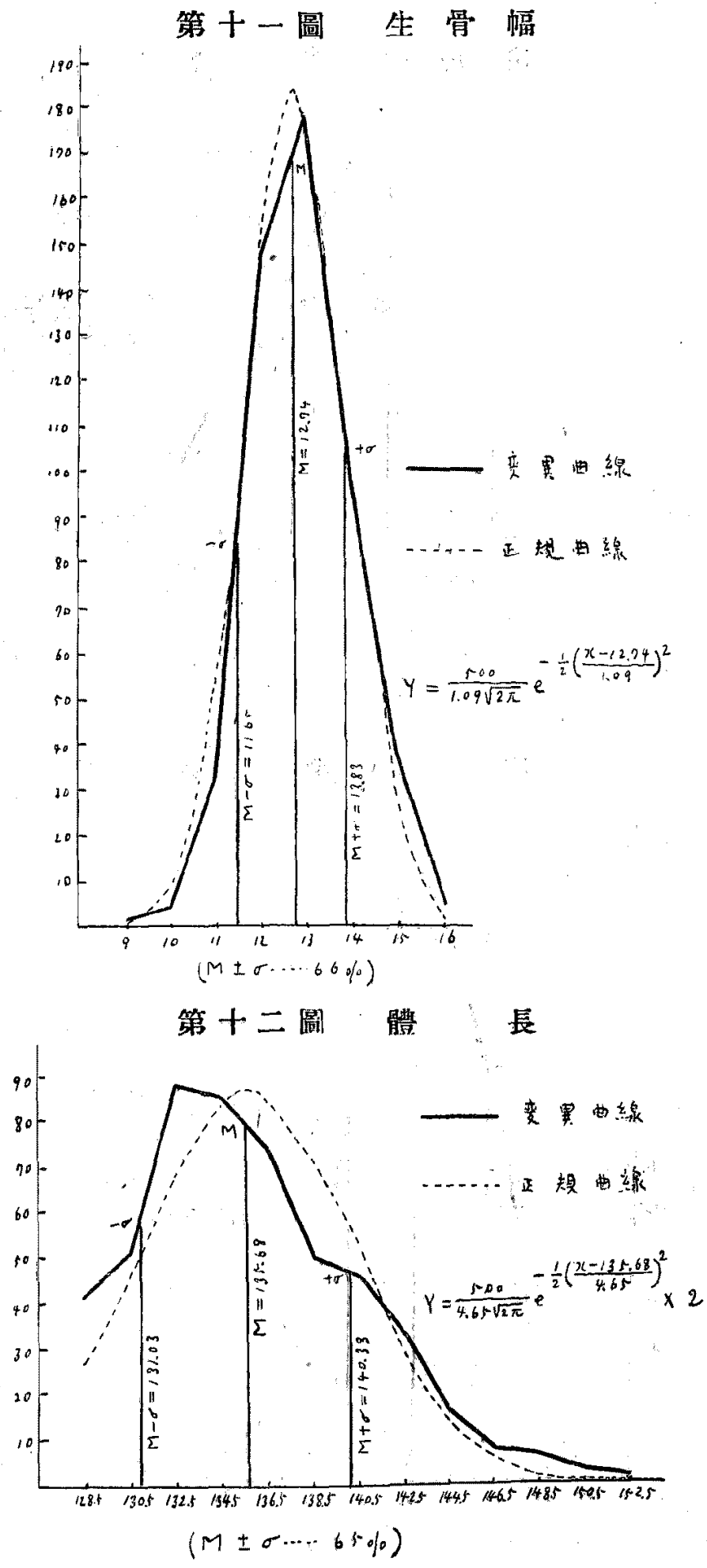
第十三圖肩 長

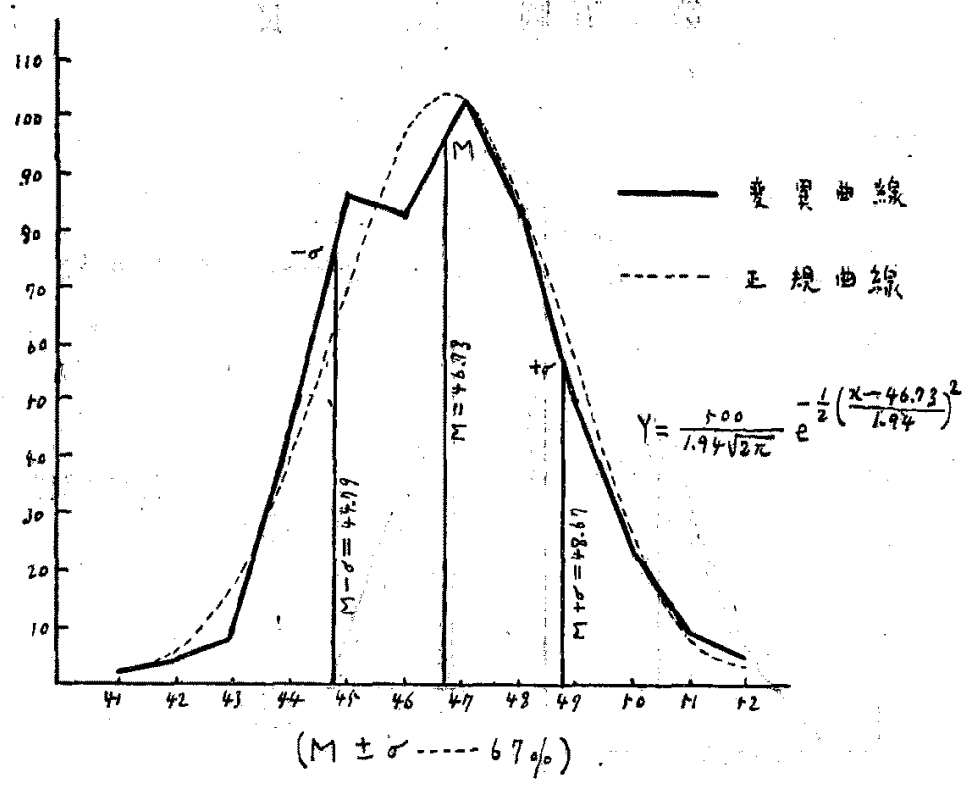

第十四圖尼長

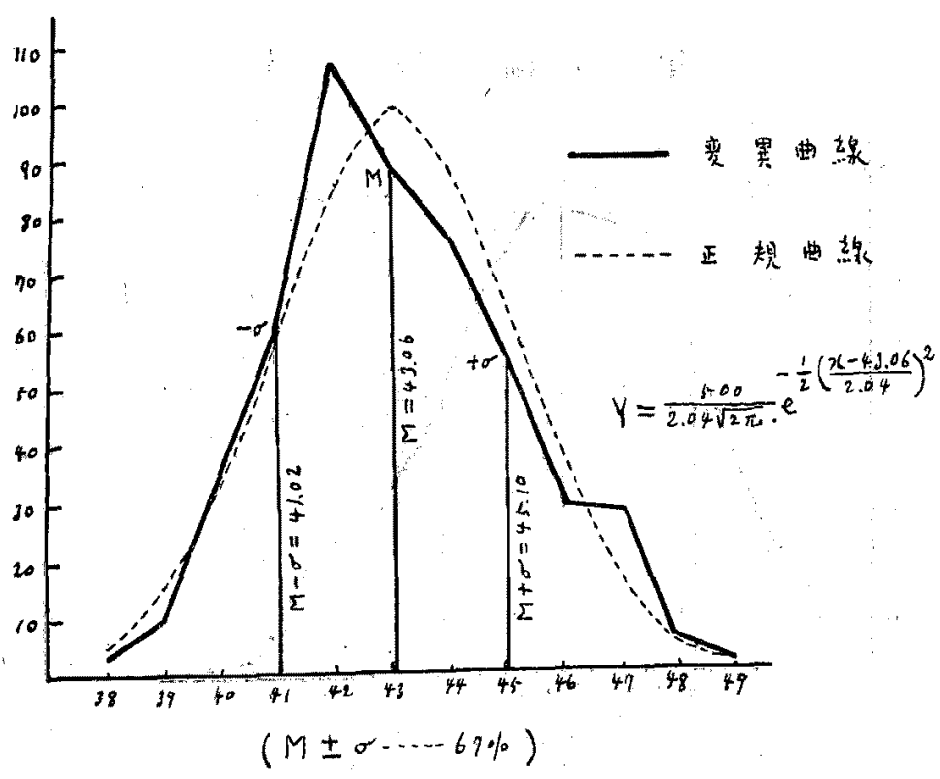


第十五圖 䫓 長

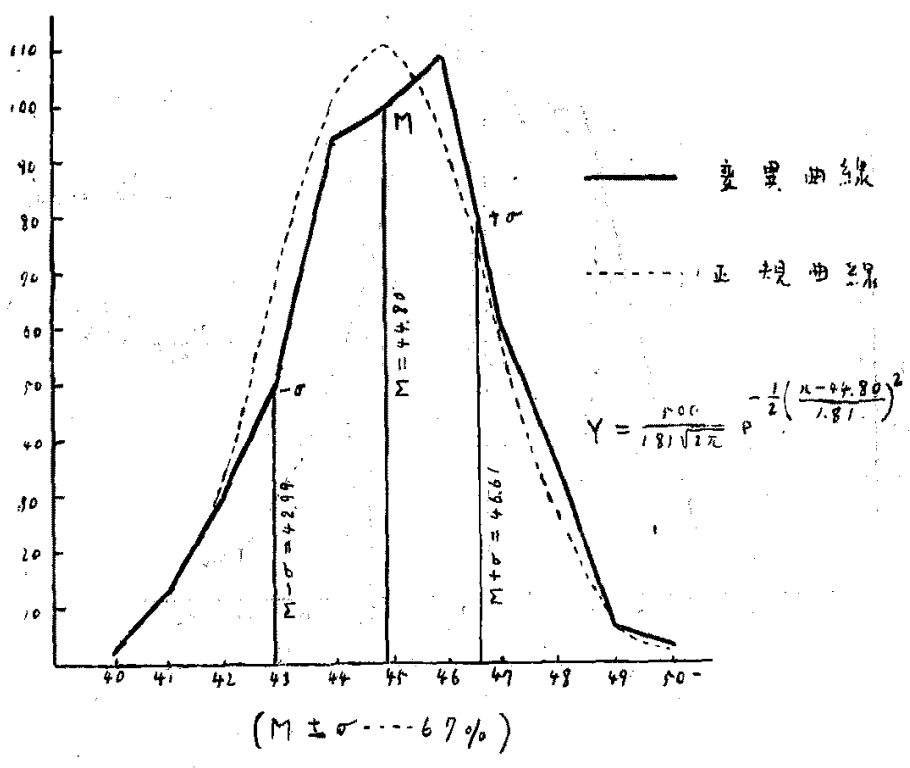

第十枀圖胸園

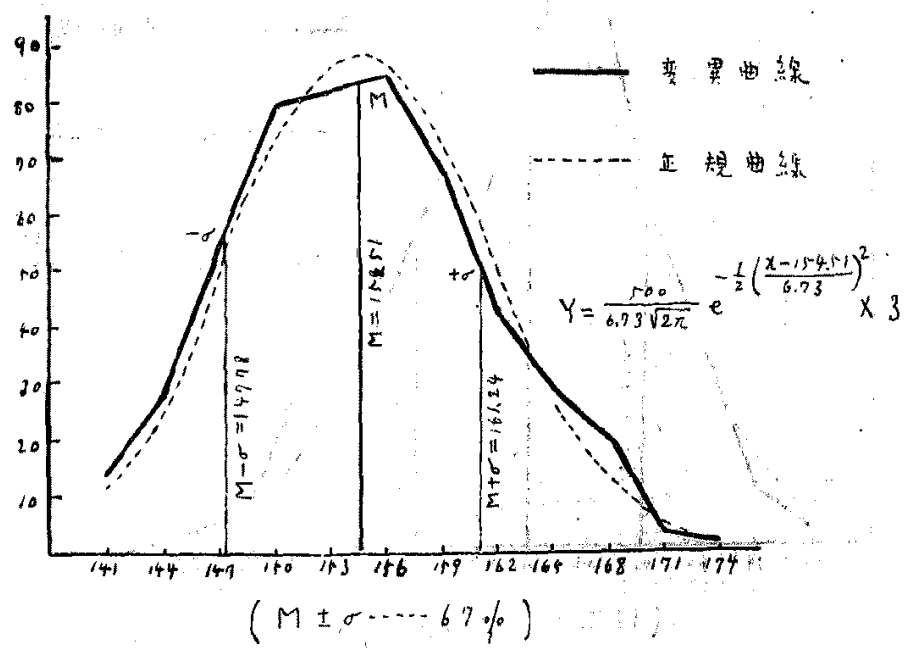




\section{第十七圖 前管圍}

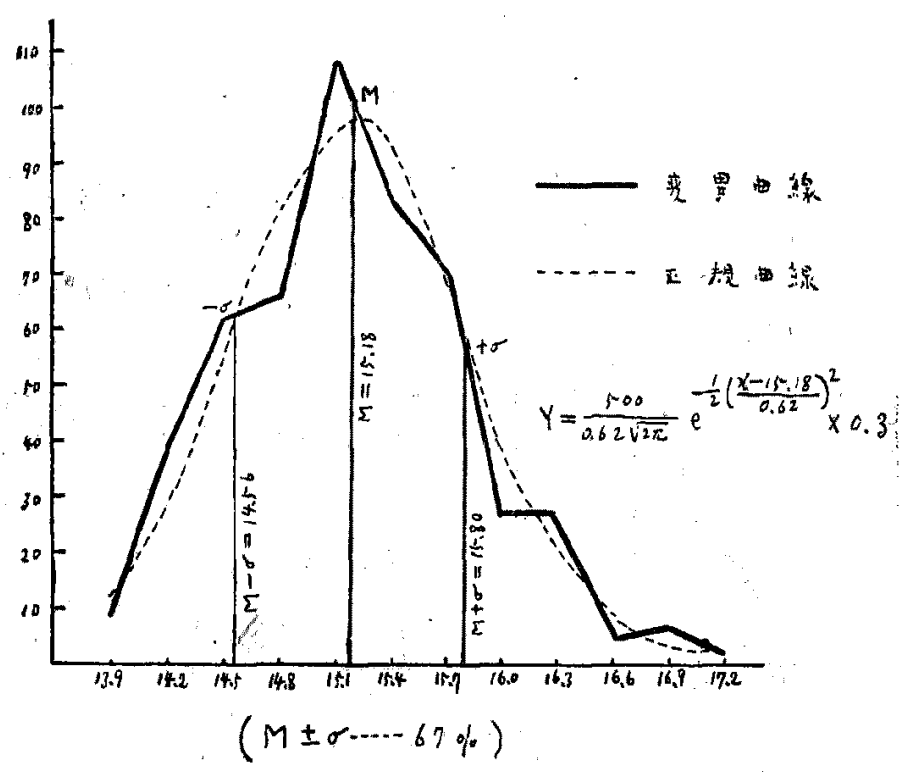

第十八圖 後 管. 圍

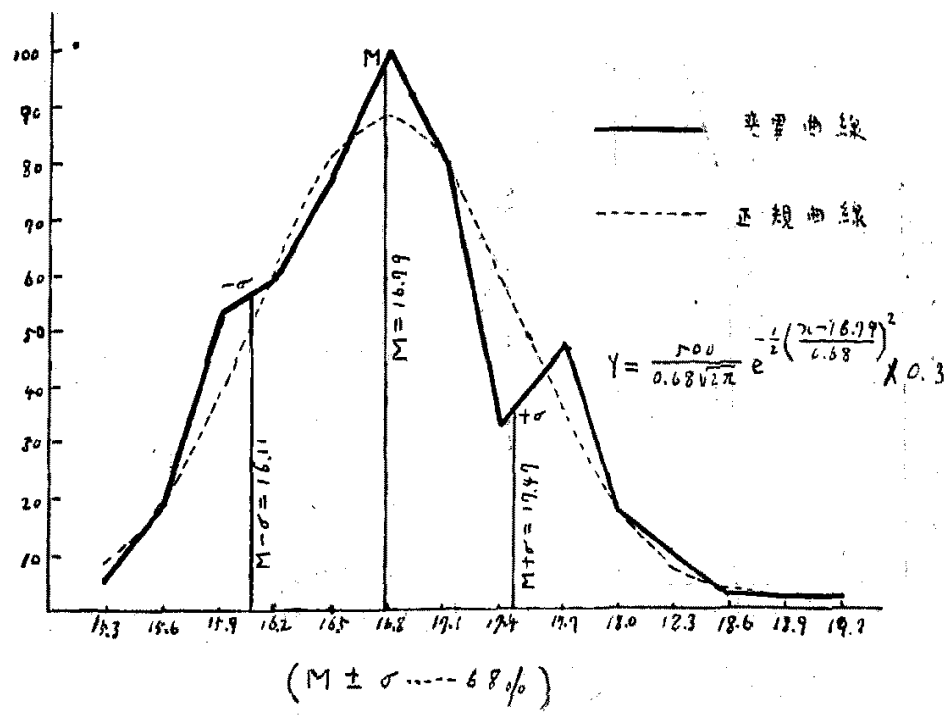


第十九圖飛節角度

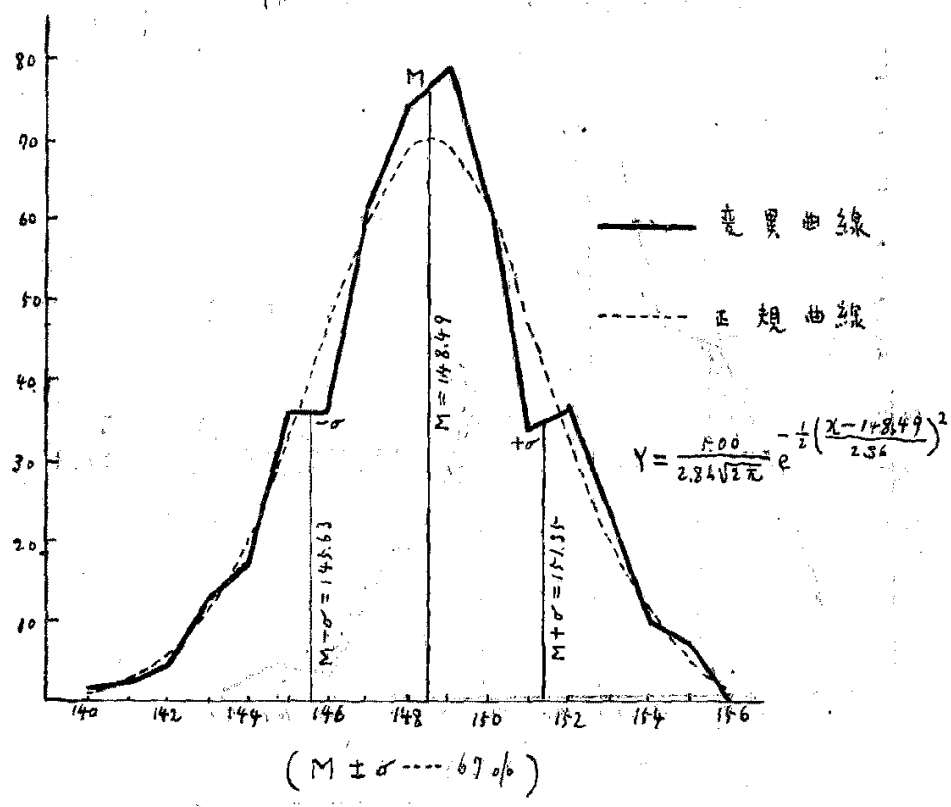

第二十圖蹬重

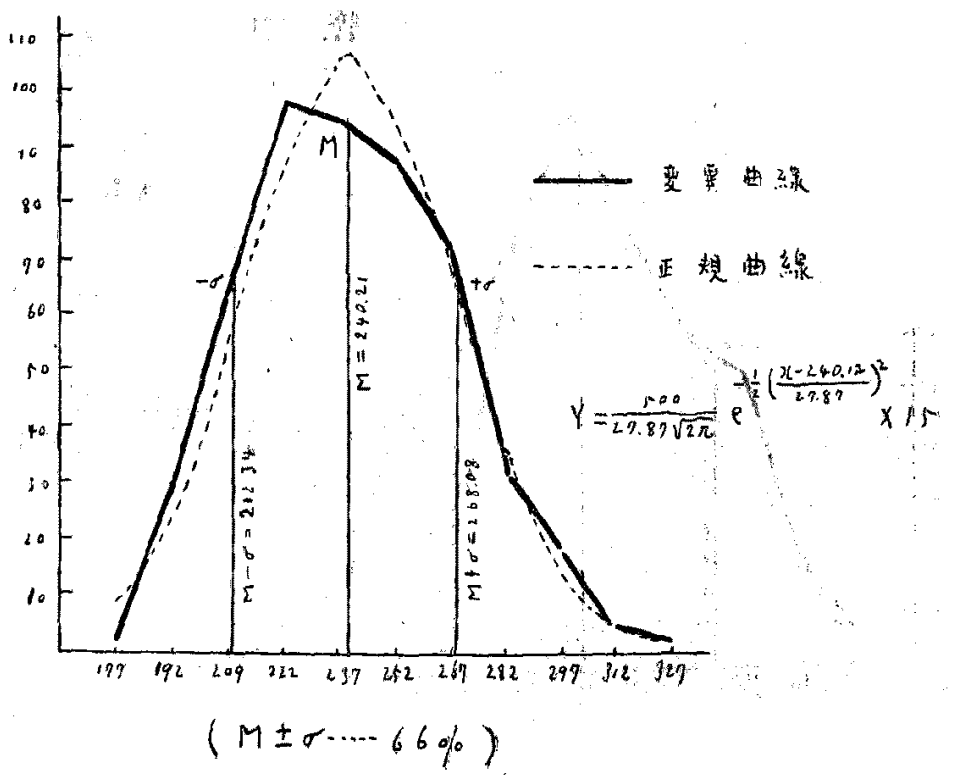




\title{
Biometric Study on Chosen Cattle. I.
}

\author{
by
}

\section{Matagorō KANADANI}

The type of Chosen cattle (Bos taurus chosenus), work breed, in South Korea is studied biometrically. Twenty physical characters in each of five hundred typical cows aged four or more, were measured by the author with special attention to the error of measurement. The biometric constant, the frequency curve as well as its fitted normal curve, are obtained, and then the goodness of fit for each curve is tested. The existence of positive correlations between thirty pairs of characters is shown, and the regression equation is found.

Thus studying analytically, the normal type of Chosen cattle in the biometric sense is determined by the application of Rautmann's method (Norm) in anthropometry. The results are briefly tabulated as follows :

1. Biometric Constant.

\begin{tabular}{|c|c|c|c|}
\hline$\underbrace{\begin{array}{c}\text { Biometric } \\
\text { Symbol }\end{array}}_{\text {Character }}$ & $\mathbf{M}$ & $\sigma$ & $\mathrm{V}$ \\
\hline Withers height & $117.66 \pm 0.108$ & $3.57 \pm 0.076$ & $3.03 \pm 0.065$ \\
\hline Hip height & $118.72 \pm 0.093$ & $3.12 \pm 0.066$ & $2.62 \pm 0.055$ \\
\hline Pine bone height & $10341 \pm 0.096$ & $3.18 \pm 0.067$ & $3.08 \pm 0.065$ \\
\hline Elbow height & $64.78 \pm 0.060$ & $2.01 \pm 0.042$ & $3.10 \pm 0.066$ \\
\hline Hock height & $44.24 \pm 0.048$ & $1.59 \pm 0.034$ & $3.59 \pm 0.076$ \\
\hline Chest depth & $62.54 \pm 0.072$ & $2.39 \pm 0.051$ & $3.81 \pm 0.081$ \\
\hline Shoulder point width & $34.18 \pm 0.065$ & $2.17 \pm 0.046$ & $6.37 \pm 0.136$ \\
\hline Chest width & $33.76 \pm 0.078$ & $2.57 \pm 0.055$ & $7.61 \pm 0.161$ \\
\hline Hip width & $41.24 \pm 0.067$ & $2.23 \pm 0.047$ & $5.40 \pm 0.115$ \\
\hline Thurl width & $37.80 \pm 0.045$ & $1.49 \pm 0.032$ & $3.94 \pm 0.084$ \\
\hline Pine bone width & $12.74 \pm 0.032$ & $1.09 \pm 0.023$ & $8.59 \pm 0.181$ \\
\hline Body length & $135.68 \pm 0.140$ & $4.65 \pm 0.099$ & $3.43 \pm 0.073$ \\
\hline Shoulder Iength & $46.73 \pm 0.059$ & $1.94 \pm 0.041$ & $4.15 \pm 0.088$ \\
\hline Rump length & $43.06 \pm 0.062$ & $2.04 \pm 0.043$ & $4.74 \pm 0.101$ \\
\hline Head length & $44.80 \pm 0.054$ & $1.81 \pm 0.038$ & $4.02 \pm 0.085$ \\
\hline Chest girth & $154.51 \pm 0.203$ & $6.73 \pm 0.143$ & $4.36 \pm 0.093$ \\
\hline Fore shin circum. & $15.18 \pm 0.019$ & $0.62 \pm 0.013$ & $4.08 \pm 0.087$ \\
\hline Hind shin circum. & $16.76 \pm 0.020$ & $0.68 \pm 0.014$ & $4.02 \pm 0.085$ \\
\hline Hock angle & $148.48 \pm 0.086$ & $2.86 \pm 0.060$ & $1.93 \pm 0.041$ \\
\hline Live weight & $240.12 \pm 0.824$ & $27.87 \pm 0.591$ & $11.60 \pm 0.259$ \\
\hline
\end{tabular}




\section{Fitted Normal Curve.}

\begin{tabular}{|c|c|c|c|}
\hline Withers height & $Y=\frac{500}{3.57 \sqrt{2 \pi}} e^{-\frac{1}{2}\left(\frac{x-117.66}{3.57}\right)^{2} \times 2}$ & IIip height & $Y=\frac{500}{3.12 \sqrt{2 \pi}} e^{-\frac{1}{2}\left(\frac{x-118.72}{3.12}\right)^{2}} \times 2$ \\
\hline Pine bone height & $Y=\frac{500}{3.18 \sqrt{2 \pi}} e^{-\frac{1}{2}\left(\frac{x-103.41}{3.18}\right)^{2}} \times 2$ & Elbow height & $Y=\frac{50 n}{2.01 \sqrt{2 \pi}} e^{-\frac{1}{2}\left(\frac{x-64.78}{2.01}\right)^{2}}$ \\
\hline Hock height & $Y=\frac{500}{1.59 \sqrt{2 \pi}} e^{-\frac{1}{2}\left(\frac{x-41,94}{1.59}\right)^{2}}$ & Chest depth & $Y=\frac{500}{2.39 \sqrt{2 \pi}} e^{-\frac{1}{2}\left(\frac{x-625-1}{2,39}\right)^{2}}$ \\
\hline $\begin{array}{l}\text { Shoulder point } \\
\text { width }\end{array}$ & $Y=\frac{500}{2.17 \sqrt{2 \pi}} e^{-\frac{1}{2}\left(\frac{x-34_{18} 18}{2.17}\right)^{2}}$ & Chest width & $Y=\frac{500}{2.59 \sqrt{2 \pi}} e^{-\frac{1}{2}\left(\frac{x-33.76}{2.59}\right)^{2}}$ \\
\hline Hip width & $Y=\frac{500}{2.23 \sqrt{2 \pi}} e^{-\frac{1}{2}\left(\frac{x-41.24}{2.23}\right)^{2}}$ & Thurl width & $Y=\frac{500}{1.49 \sqrt{2 \pi}} e^{-\frac{1}{2}}\left(\frac{x-37.80}{1.49}\right)^{2}$ \\
\hline Pine bone width & $Y=\frac{500}{1.09 \sqrt{2 \pi}} e^{-\frac{1}{2}\left(\frac{x-12.74}{1.09}\right)^{2}}$ & Budy length & $Y=\frac{500}{4.65 \sqrt{2 \pi}} e^{-\frac{1}{2}\left(\frac{x-135.68}{4.65}\right)^{2} \times 2}$ \\
\hline Shoulder length & $Y=\frac{500}{1.94 \sqrt{2 \pi}} e^{-\frac{1}{2}\left(\frac{x-46.78}{1.94}\right)^{2}}$ & Rump length & $Y=\frac{500}{2.04 \sqrt{2 \pi}} e^{-\frac{1}{2}\left(\frac{x-43,06}{3.04}\right)^{2}}$ \\
\hline Head length & $Y=\frac{5,0}{1.81 \sqrt{2 \pi}} e^{-\frac{1}{2}\left(\frac{x-44.80}{1.81}\right)^{2}}$ & Chest girth & $Y=\frac{500}{6.73 \sqrt{2 \pi}} e^{-\frac{1}{2}\left(\frac{x-154,51}{6.78}\right)^{2}} \times 3$ \\
\hline Fore shin circum & $Y=\frac{500}{0.62 \sqrt{2 \pi}} e^{-\frac{1}{2}\left(\frac{x-15,18}{0.62}\right)^{2}} \times 0.3$ & $\begin{array}{l}\text { Hind shin } \\
\quad \text { circum. }\end{array}$ & $Y=\frac{500}{0.68 \sqrt{2 \pi}} e^{-\frac{1}{2}\left(\frac{n-16,79}{0.68}\right)^{2}} \times 0.3$ \\
\hline Hock ąngle & $Y=\frac{500}{2.86 \sqrt{2 \pi}} e^{-\frac{1}{2}\left(\frac{x-148,48}{2.86}\right)^{2}}$ & Live weight & $Y=\frac{5110}{27.87 \sqrt{2 \pi}} e^{-\frac{1}{2}\left(\frac{x-240.18}{27.87}\right)^{2}} \times 15$ \\
\hline
\end{tabular}

\section{Correlation Coefficient.}

Table 1.

\begin{tabular}{|l|l|l|}
\hline Character & Withers height & Body length \\
\hline Body length & $+0.57 \pm 0.020$ & \\
Hip height & $+0.80 \pm 0.011$ & $+0.52 \pm 0.022$ \\
Elbow height & $+0.66 \pm 0.017$ & $+0.33 \pm 0.027$ \\
Chest depth & $+0.61 \pm 0.019$ & $+0.61 \pm 0.019$ \\
Chest width & $+0.34 \pm 0.027$ & $+0.26 \pm 0.028$ \\
Hip width & $+0.43 \pm 0.025$ & $+0.65 \pm 0.017$ \\
Chest girth & $+0.52 \pm 0.022$ & $+0.51 \pm 0.022$ \\
Fore shin circum. & $+0.51 \pm 0.022$ & $+0.52 \pm 0.022$ \\
Head length & $+0.35 \pm 0.027$ & $+0.31 \pm 0.027$ \\
Rump length & $+0.55 \pm 0.021$ & $+0.65 \pm 0.017$ \\
Live weight & $+0.45 \pm 0.024$ & $+0.60 \pm 0.019$ \\
\hline
\end{tabular}


Table 2.

\begin{tabular}{|l|c|}
\hline \multicolumn{1}{|c|}{ Character Correlated } & I \\
\hline Flbow height and Hock height & $+0.61 \pm 0.019$ \\
Elbow height and Shoulder length & $+0.42 \pm 0.025$ \\
Hip width and Chest width & $+0.48 \pm 0.023$ \\
Hip width and Thurl width & $+0.76 \pm 0.013$ \\
Hip width and Rump length & $+0.64 \pm 0.018$ \\
Fore shin circum. and Chest girth & $+0.60 \pm 0.019$ \\
Fore shin circum. and Hind shin circum. & $+0.81 \pm 0.010$ \\
Fore shin circum, and Head length & $+0.44 \pm 0.024$ \\
Chest girth and tive weight & $+0.75 \pm 0.013$ \\
\hline
\end{tabular}

\section{Regression Equation.}

\begin{tabular}{|c|c|c|c|c|c|}
\hline Withers height, & $X$ & Hip height, & $Y$ & $X=0.92 Y+8.44$ & $Y=0.70 X+36.36$ \\
\hline Withers height, & $X$ & Elbow height, & $Y_{1}$ & $X=1.17 Y_{1}+41.87$ & $Y_{1}=0.37 X+21.25$ \\
\hline Withers height, & $X$ & Chest depth, & $Y_{2}$ & $X=0.91 Y_{2}+60.75$ & $Y_{2}=0.41 X+14.30$ \\
\hline Withers height, & $X$ & Chest width, & $Y_{3}$ & $X=0.47 Y_{3}+101.79$ & $Y_{3}=0.24 X+5.52$ \\
\hline Withers height, & $X$ & Hip width, & $Y_{4}$ & $X=0.69 Y_{4}+89.20$ & $Y_{4}=0.27 X+9.47$ \\
\hline Withers height, & $X$ & Body Jength, & $Y_{5}$ & $X=0.44 Y_{\S}+57.96$ & $Y_{5}=0.74 X+48.61$ \\
\hline Withers height, & $X^{5}$ & Rump length, & $Y_{\mathfrak{n}}^{\prime}$ & $X=0.96 Y_{6}+76.32$ & $1 X+6.59$ \\
\hline Withers height; & $X$ & Head length, & $Y_{7}$ & $X=0.69 Y_{7}+86.75$ & $Y_{7}=0.18 X+23.62$ \\
\hline Withers height, & $X$ & Chest girth, & $Y_{8}$ & $0.28 Y_{8}+74.40$ & $8 X+39.20$ \\
\hline Withers height, & $X$ & Fore shin circum. & $Y_{9}$ & $X=0.94 Y_{9}+73.09$ & $Y_{9}=0.09 X+4.59$ \\
\hline Withers height, & $X$ & Live weight, & $Y_{10}$ & $06 Y_{10}+103.25$ & $51 X-172.78$ \\
\hline Thurl width, & $X_{1}$ & Mip width, & $Y_{4}$ & $X_{1}=0.51 Y_{4}+16.77$ & $Y_{4}=1.14 X_{1}+1.85$ \\
\hline Hock height, & $X_{2}$ & Elbow heigut, & $Y_{1}$ & $X_{2}=0.48 Y_{1}+13.15$ & $Y_{1}=0.77 X_{2}+30.72$ \\
\hline Hind shin circum. & $X_{3}$ & Fore shin circum. & $Y_{9}$ & $X_{3}=0.89 Y_{9}+3.28$ & $4 X_{3}+2.76$ \\
\hline Head length, & $Y_{7}$ & Fore shin circum. & $Y_{0}$ & $Y_{7}=1.28 Y_{9}+25.37$ & $Y_{9}=0.15 Y_{7}$ \\
\hline IIip width, & $\mathrm{H}_{4}$ & Rump length, & $\boldsymbol{Y}_{6}$ & $Y_{4}=0.70 Y_{6}+11.10$ & $Y_{6}=0.59 Y+18.73$ \\
\hline Chest girth, & $\mathrm{Hs}$ & Fore shin circum. & $Y_{0}$ & $Y_{\mathrm{S}}=6.51 Y_{9}+55.69$ & $Y_{8}=0.06 Y_{8}+5.91$ \\
\hline Body length, & $\mathrm{H}^{5}$ & Chest girth, & $Y_{8}$ & $Y_{5}=0.35 Y_{8}+81.60$ & $Y_{8}=0.74 Y+54.11$ \\
\hline Body length, & $\mathrm{Hs}$ & Live weight, & $Y_{10}$ & $Y_{5}=0.10 Y_{10}+111.66$ & $Y_{10}=3.60 Y_{5}-248.24$ \\
\hline Chest girth, & H8 & Live weight, & $Y_{10}$ & $Y_{8}^{\top}=0.18 Y_{10}+111.27$ & $Y_{10}=3.11 Y_{8}-240.32$ \\
\hline
\end{tabular}

5. Normal Type.

\begin{tabular}{|l|c|}
\hline \multicolumn{1}{|c|}{ Character } & $(\mathrm{M}-\sigma)-(\mathrm{M}+\sigma)$ \\
\hline Withers height & $114-121$ \\
Chest depth & $60-64$ \\
Chest width & $31-\mathbf{3 6}$ \\
Hip width & $39-\mathbf{4 3}$ \\
Body length & $\mathbf{1 3 1 - 1 3 9}$ \\
Rump length & $\mathbf{4 1 - 4 5}$ \\
Chest girth & $\mathbf{1 4 8 - 1 6 0}$ \\
Fore shin circum. & $\mathbf{1 5 - 1 6}$ \\
\hline
\end{tabular}

(Zootechnical Laboratory, Department of Agriculture, Kyushu Imperial University, Fukuoka, Japan.) 